\title{
La representación artística de la ciudad de Santiago. Leyendas y escrituras
}

\author{
Miguel ETAYO GORDEJUELA \\ I.E.S. Beatriz Galindo \\ migueletayo@telefonica.net
}

Recibido: 15 de febrero de 2011

Aceptado: 16 de mayo de 2011

\section{Resumen}

La experiencia y el mito, las leyendas y la más documentada y minuciosa observación constituyen una mezcla aparentemente contradictoria pero muy característica del conocimiento propio de la plena Edad Media. El cruce de informaciones contenidas en diferentes documentos de los siglos XI y XII nos acerca a la imagen que de la ciudad santa se hicieron quienes la visitaron u oyeron hablar de ella: uno es gráfico, el mapamundi del Beato de Osma (1086); otro un conocido texto, el Liber Peregrinationis de Aymeric Picaud, de mediados del siglo siguiente; el tercer documento es enorme, es la catedral románica entonces en construcción: sus imágenes nos servirán para cotejar lo que describe Picaud.

Palabras clave: Catedral de Santiago, Beato de Osma, Códice Calixtino, ciudades míticas.

Title: The artistic representation of the city of Santiago. Legends and writings
Abstract check what Picaud describes. cities.

\section{Índice}
1. El mito fundacional: la invención de la tumba del Apóstol
2. El mapamundi del Beato de Osma (1086)
3. El Liber Peregrinationis de Aymeric Picaud
4. La catedral
5. El pórtico Norte
6. El pórtico Sur
7. El pórtico Oeste

Experience and myth, legends and the most documented and meticulous observation constitute an apparently contradictory mixture, very characteristic of High Middle Ages' knowledge. By crossing information from different documents of 11 th and 12 th centuries we approach to the image of the holly city made by those who visited it or heard about it. One of them is a graphic witness: Beato de Osma's world map (1086); the other one, a well-known text: the Liber Peregrinationis by Aymeric Picaud, written in the middle of the following century; the third document is a huge one: the Roman cathedral then under construction, whose images will be used to

Keywords: Santiago Cathedral, Beato de Osma, Codex Calixtinus, mitical 


\section{El mito fundacional: la invención de la tumba del Apóstol}

Santiago de Compostela es una ciudad santa, uno de los tres principales santuarios de la Cristiandad. ¿Cómo se la representaban en plena Edad Media, pasado el año 1000, en los siglos en que más brillaba su fama? ¿Dónde decían que estaba? ¿Cómo era y qué cosas ocurrían allí? Muchos la conocieron en persona, puesto que en sus mejores años el Camino de Santiago llegaba a conducir entre 200.000 y 500.000 peregrinos (Bravo Lozano 1989: 5). Se puede afirmar que en aquella época había en el Occidente europeo un considerable acopio de datos ciertos sobre una importante extensión del mundo, datos topográficos y de carácter práctico de los principales países europeos y del Próximo Oriente: las Cruzadas desde finales del siglo XI y en el siglo XII llevaron a mucha gente por tierra hasta Constantinopla y a cruzar el Mediterráneo y el Egeo; las peregrinaciones, a Roma, Santiago y Jerusalén; a ello se añadía la expansión del comercio a larga distancia y la creación de factorías por todo el Mediterráneo e incluso el Mar Negro, etc. Por la mayoría de las ciudades europeas pasaban entonces personas que habían recorrido distancias considerables (Wade Labarge 1992: 21-22).

La tumba de Santiago se descubre a principios del siglo IX en el Campo de Estrella, Compostela, donde había una necrópolis romana y luego sueva. El relato del descubrimiento está en la Concordia de Antealtares (1077), que narra cómo en algún momento -datado entre los años 820 y $834-$ un eremita, llamado Pelayo, vio unas luminarias sobre aquel lugar y lo puso en conocimiento de Teodomiro, obispo de la diócesis de Iria Flavia, quien encontró el mausoleo del apóstol. Cuando el monarca asturiano Alfonso II (791-842) lo supo, mandó levantar en aquel lugar una pequeña iglesia para el culto jacobeo. Es posible que en realidad viniera transmitiéndose, de un obispo a otro de Iria Flavia, la tradición de que los restos del apóstol se hallaban por allí (Muñoz Jiménez 2010: 443). Modernamente no se considera probada la autenticidad del sepulcro y, en el año 1900, el hagiógrafo Louis Duchesne sugiere que quien realmente está enterrado en Compostela es el herético obispo Prisciliano (siglo IV), teoría de la que se hicieron eco, por ejemplo, Sánchez-Albornoz y Unamuno.

De ser cierto que está en Compostela, Santiago sería el único apóstol enterrado en Occidente, además de San Pedro y San Pablo en Roma. Como Jerusalén, Santiago de Compostela se convierte así en meta de peregrinaciones, en un santuario cristiano avanzado frente al infiel. El ambiente para la inventio había sido preparado en los siglos anteriores: la Carta del obispo León de Jerusalén dirigida a francos, vándalos, visigodos y ostrogodos, y datable por tanto en torno al año 500 , es el primer texto que habla de que Santiago está enterrado en España. Es un relato de la traslación del cuerpo lleno de aventuras y 
prodigios que acaba con una exhortación a acudir a orar a Occidente porque "ciertamente allí yace oculto Santiago".

También el Breviario de los Apóstoles, texto latino redactado a finales del siglo VI, ubica el enterramiento de Santiago en Occidente, en un lugar llamado "Arca Marmárica". Pero se duda de la autenticidad de este texto ya desde el siglo VII: Julián de Toledo rechazó tajantemente la predicación de Santiago en España. No obstante, hacia el 700, el obispo de Sherborn, Adhelmo, dedica a Santiago un poema que habla de cómo convirtió Hispania, donde está "su excelso altar". El monje inglés Beda el Venerable (673-735) todavía va más lejos: no sólo ratifica la noticia del Breviarium apostolorum, sino que ubica el cuerpo del apóstol en Galicia.

El Comentario del Apocalipsis de Beato de Liébana (786) dice que Santiago es el evangelizador de España. En el Libro II, Beato afirma que a Santiago Apóstol se le asignó evangelizar España; a su hermano Juan, Asia, y a Pedro, Roma. Recuerda la petición a Jesús de la madre de los Zebedeos: que se sentaran en Su Reino uno a la derecha y el otro a la izquierda, lo que se traduciría por uno al Occidente y otro al Oriente. Entre los siglos X y XIII se elaboraron muchas copias de esta obra. De las veintisiete conservadas, veinticuatro contienen miniaturas y algunas incorporan mapas que ilustran un pasaje concreto de los Comentarios al Apocalipsis de San Juan en el que se divide el orbe entre los apóstoles, adjudicando a cada uno de ellos la parte del mundo que les corresponde evangelizar: "Haec est ecclesia per universum orbem dilata". El mismo monje Beato de Liébana es autor de un Himno para el día de Santiago Apóstol, hermano de San Juan, conocido como O dei verbum.

\section{El mapamundi del Beato de Osma (1086)}

Beato de Osma pone la ciudad de Santiago en el mapa del mundo; un mundo plano de forma circular, con el Paraíso arriba regado por cuatro ríos, y retratos de los doce apóstoles, cada uno de ellos en su lugar de evangelización. Sólo dos de los Apóstoles, Pedro en Roma y Santiago en Compostela, están "entronizados" en sus sedes o cátedras. Ello representa que las dos sedes son apostólicas y metropolitanas (figura 1). 


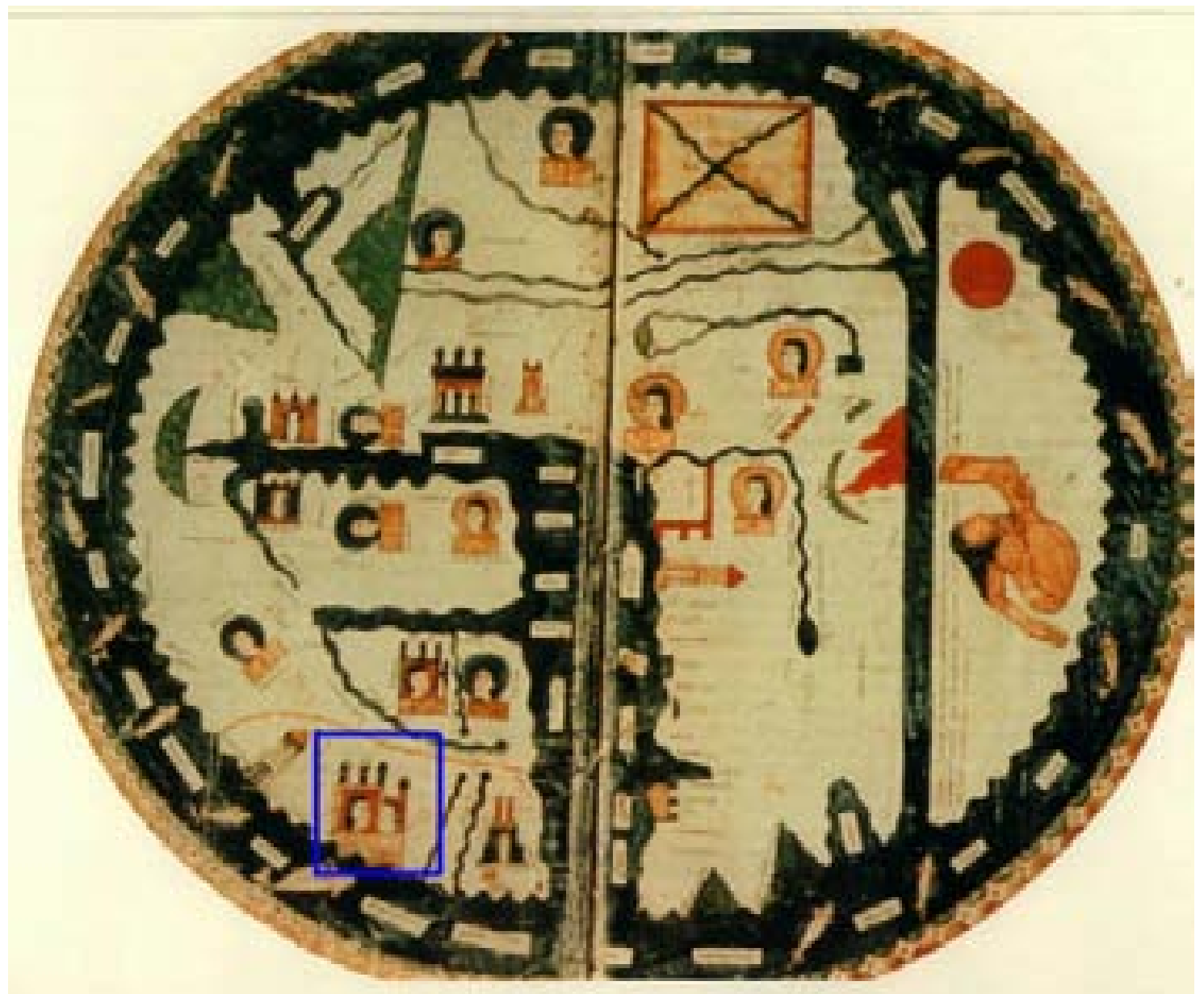

Figura 1. Mapamundi del Beato de Osma.

Empecemos contemplando otro ejemplo muy completo: el del Beato de Saint-Sever, un poco anterior (1060-1070). La tierra se representa efectivamente circular, plana y con los tres continentes del viejo mundo. A este tipo de mapas se los denomina, por su forma, de "T en $\mathrm{O}$ ". Parten de un diagrama muy simple que aparece en las Etimologías de Isidoro de Sevilla (560-636), ajustado a la descripción de la tierra que en ellas se hace (figura 2 ). 


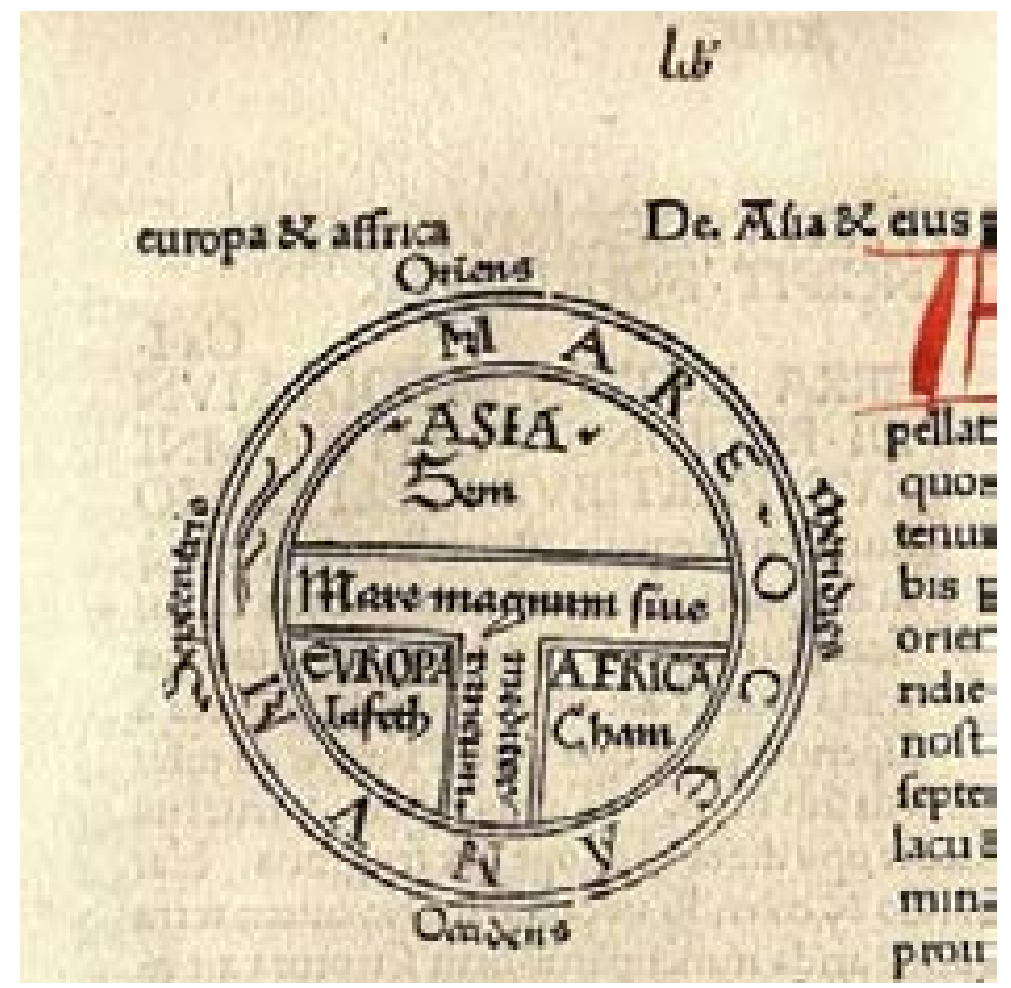

Figura 2. Etimologías de San Isidoro.

Se trata de un mapa "orientado", es decir, que mira a Oriente, situado arriba, donde está el Paraíso, como si fuera la clave del arco: allí están Adán y Eva, el árbol y la serpiente. También están los cuatro ríos que allí brotan y van a desembocar al mar periférico. Sus nombres eran Tigris, Eufrates, Geón y Fisón. La barra transversal de la $T$ representa una línea continua formada por el Nilo, el Helesponto, el Ponto Euxino (mar Negro), el Palus Maeotis (mar de Azov) y el río Tanais (Don). Esta franja separa Asia, en la mitad superior del mapa, de los otros dos continentes. La pata de la T corresponde al Mar Mediterráneo y divide la mitad inferior del mapa dejando Europa a la izquierda y África a la derecha. Cada continente se atribuye a uno de los hijos de Noé. Asia está habitada por los pueblos semitas, descendientes de Sem, África por los camitas y Europa por los descendientes de Jafet. El mar Rojo se pinta de este color. 


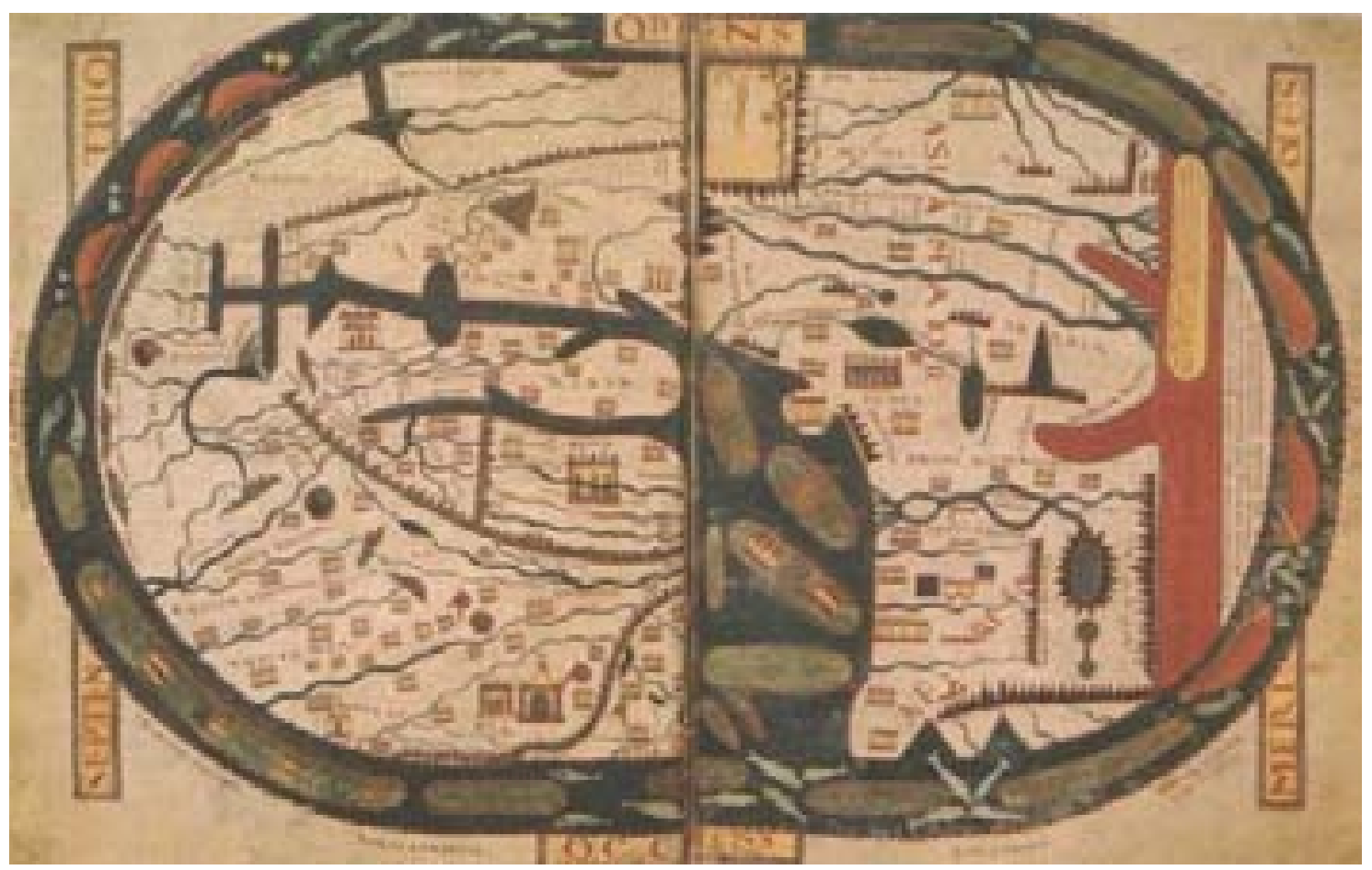

Figura 3. Mapamundi del Beato de Saint-Sever.

Se trata de una geografía simbólica. El mapamundi ofrece, claramente, dos tipos de espacios. El circular y ordenado de la tierra y el informe y caótico de las aguas; el Midgard de los germanos, o mundo de los humanos, y el Utgard o mundo caótico de monstruos y gigantes que lo rodea. Los espacios terrestres muestran, igualmente, una jerarquía simbólica: en el centro aparece Jerusalén, y ríos y mares separan la cristiana Europa de las tierras infieles (figura 3).

Volviendo ya al mapa del Beato de Osma, la geografía de la Península Ibérica está especialmente detallada en la región de la "Gallecia", la antigua Gallaecia romana (figura 4). La figura de Santiago el Mayor, "S. Iacobs aps.", se asienta sobre un santuario en las proximidades del faro de La Coruña ("Faro"). Aparecen cerca los ríos Miño ("F. Minneus") y Duero ("F. Durius") y el territorio de Asturias. Por cierto que en este mapa aparecen muy lejos, al Sur, en el extremo derecho del mapa, las antípodas, con un extraño hombre que se protege del intenso sol con su único y enorme pie (figura 1). 


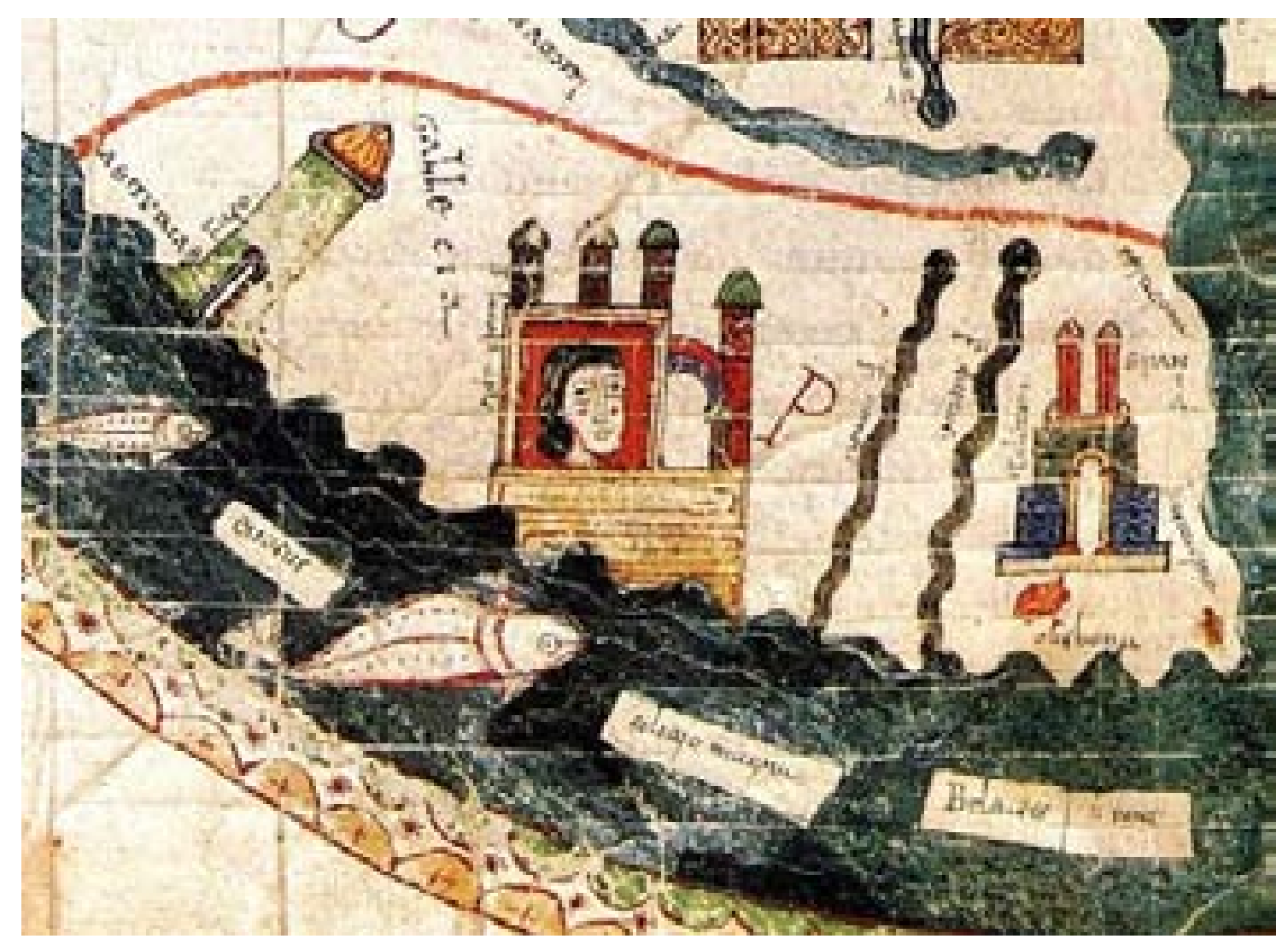

Figura 4. Detalle del mapamundi del Beato de Osma.

La cartografía del Medioevo se había vuelto hacia lo legendario, lo religioso y lo simbólico. Todavía en los siglos XIV y XV encontramos los últimos ejemplos de mapas de "T en O" (figura 5); mapas de escasa utilidad práctica para los verdaderos viajeros, por mucho que se pueda disfrutar con sus fantasías (Wade Labarge 1992: 33).

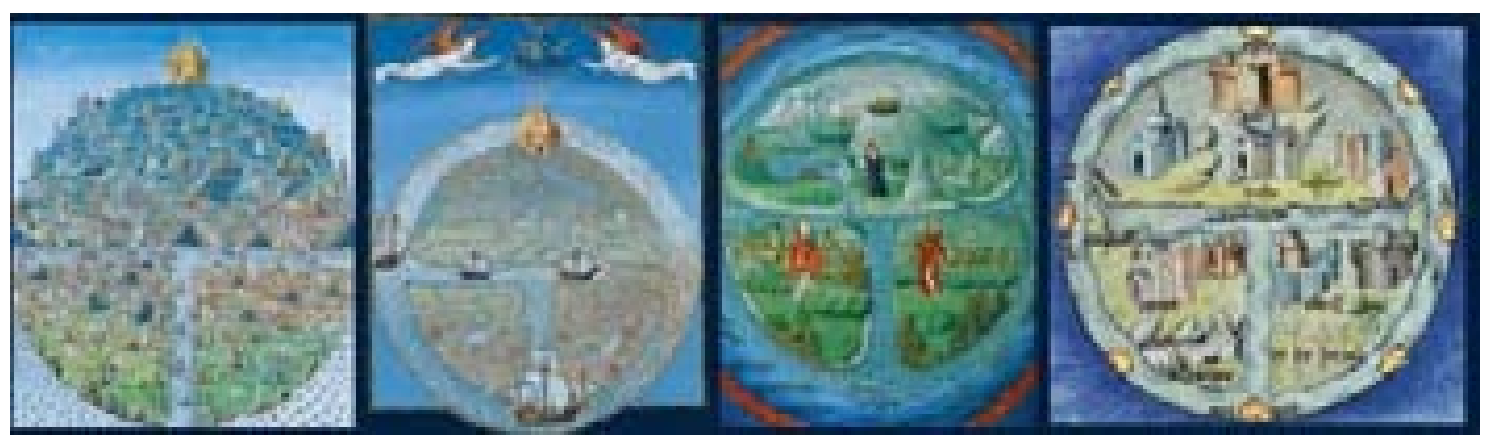

Figura 5. Mapas tardíos de "T en O".

A partir del siglo XIII se trazan ya algunos itinerarios, diagramas de rutas como los que hubo también en el Imperio Romano, como éste de Matthew Paris entre Bar-sur-Seine y Troyes (figura 6). Estos itinerarios son como la réplica cartográfica de una guía de viaje al estilo de la de Aymeric Picaud, que estudiaremos a continuación. 


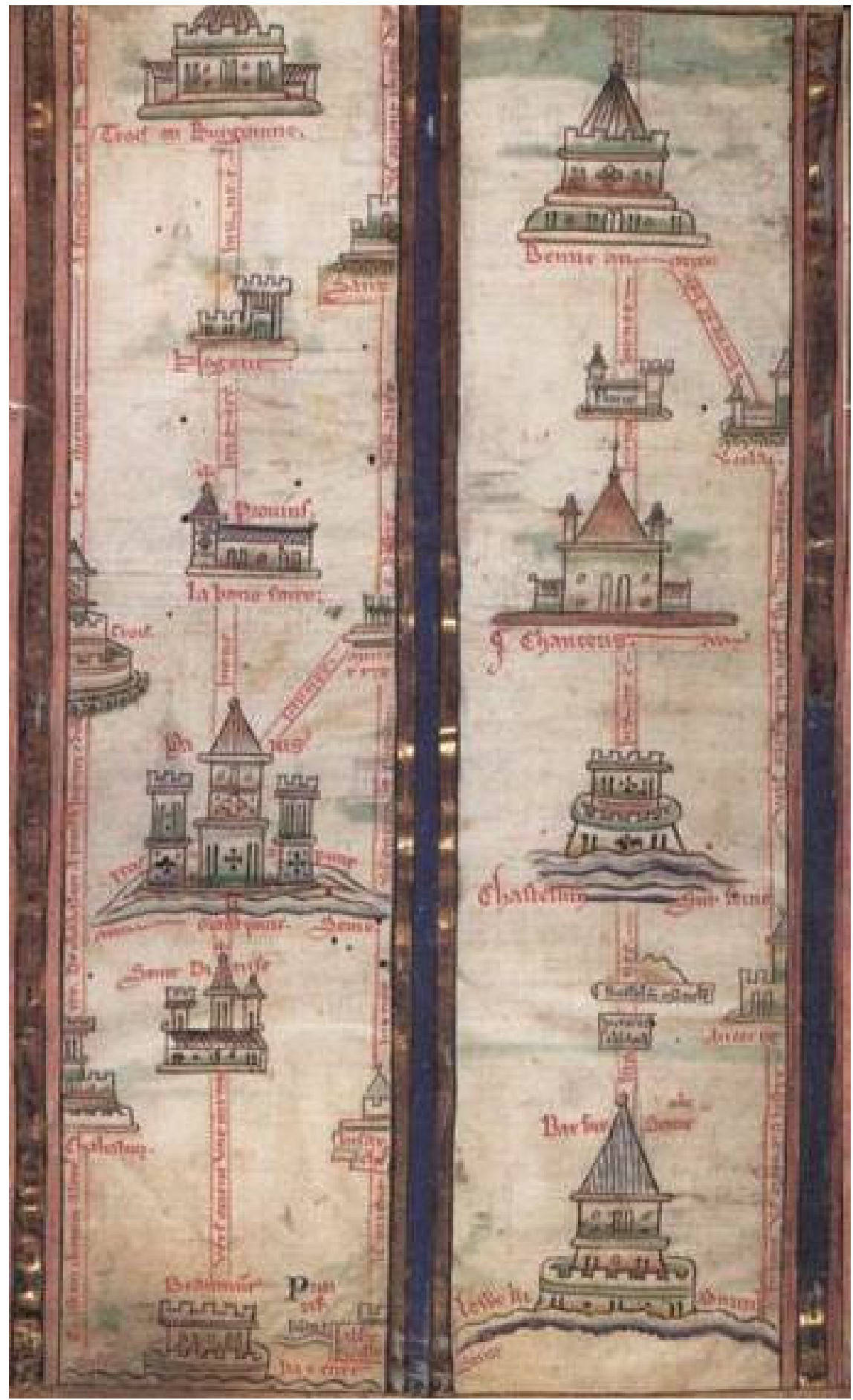

Figura 6. Itinerario de Matthew Paris.

\section{El Liber Peregrinationis de Aymeric Picaud}

A mediados del siglo XII aparece el Liber Sancti Jacobi o Codex Calixtinus, que viene a cerrar el desarrollo mitológico de la figura del apóstol (matamoros, peregrino él mismo...) y pretende promocionar la peregrinación. Para ello, incluye en sus cinco partes: 1) un amplio conjunto de textos y formularios de liturgia; 2) una colección de 
milagros del Apóstol en distintos lugares de Europa; 3) un relato de la traslación de su cuerpo a Galicia; 4) el Pseudo-Turpín o relato de la intervención de Carlomagno en España y su participación en el descubrimiento del sepulcro, y 5) la Guía del Camino, el texto del que nos vamos a ocupar, obra del monje cluniacense Aymeric Picaud, probablemente canciller del papa Calixto II (que también procede de la comunidad de Cluny, tan activa en la promoción y organización del Camino).

Picaud informa sobre las condiciones del Camino y, como otros viajeros medievales, se interesa por aspectos prácticos como los productos de cada comarca o la salubridad de sus aguas. También imparte consejos morales, reclama para el peregrino el máximo respeto y la mejor acogida, y, sobre todo, alaba la Catedral de Santiago. En el capítulo III, dice de la ciudad:

Compostela, la excelsa ciudad del Apóstol, repleta de todo tipo de encantos, la ciudad que custodia los restos mortales de Santiago, motivo por el que está considerada como la más dichosa y excelsa de las ciudades de España. (Bravo Lozano 1989: 23) ${ }^{1}$

Después de dar una imagen muy negativa de los habitantes de España en los capítulos VI (sobre los navarros) y VII (otra vez de los navarros y también sobre los castellanos), elogia en cambio a los gallegos al final de este último capítulo: "Los gallegos son el pueblo que, entre los demás pueblos incultos de España, más se asemejan a nuestra nación gala, si no fuera porque son muy iracundos y litigiosos".

El capítulo IX está dedicado a la ciudad y a la basílica. A la ciudad profana, la de la dimensión material del hombre, corresponden sólo unas pocas líneas, las justas para conducir al peregrino hacia la basílica del apóstol:

La ciudad de Compostela está situada entre dos ríos llamados Sar y Sarela. El Sar se encuentra al oriente entre el Monte del Gozo y la ciudad, y el Sarela al poniente. Las entradas y puertas de la ciudad son siete. La primera entrada se llama Puerta Francesa; la segunda, Puerta de la Peña; la tercera, Puerta de Sofrades; la cuarta, Puerta del Santo Peregrino; la quinta, Puerta Falguera, que conduce a Padrón; la sexta, Puerta de Susannis; y la séptima, Puerta de Mazarelos, por la que llega el precioso licor de Baco a la ciudad.

\section{LAS IGLESIAS DE LA CIUDAD}

Habitualmente se cuentan en esta ciudad 10 iglesias, entre las que, situada en el centro, resplandece gloriosa como la más importante, la del gloriosísimo apóstol Santiago, el hijo del Zebedeo [...].

\footnotetext{
${ }^{1}$ Todas las citas de la Guía del camino de Aymeric Picaud están extraídas de esta edición del Códice Calixtino.
} 
El nacimiento de Santiago de Compostela está ligado al descubrimiento del sepulcro, un nuevo lugar de peregrinación de la cristiandad en un momento en que Jerusalén estaba en poder de los musulmanes. Primero se estableció una comunidad eclesiástica permanente al cuidado de los restos, formada por el obispo de Iria y los monjes de Antealtares, junto a la que se fue asentando una población que aumentó a medida que progresaba la peregrinación. El santuario acogió la coronación de sucesivos reyes de Galicia y de León. Sisenando II fortificó en el año 969 el Locus Sancti Iacobi (de apenas 2 hectáreas, donde iba a perdurar la Compostela catedralicia), y cercó con una empalizada un nuevo recinto mucho más amplio (unas 30 hectáreas), que se mantuvo con la misma forma y tamaño hasta el derribo de las murallas en la primera mitad del siglo XIX, como se puede ver todavía en el siguiente plano de 1901 (figura 7), cuando vivían en la ciudad 15.000 habitantes (en la actualidad, residen en Santiago unas 100.000 personas).

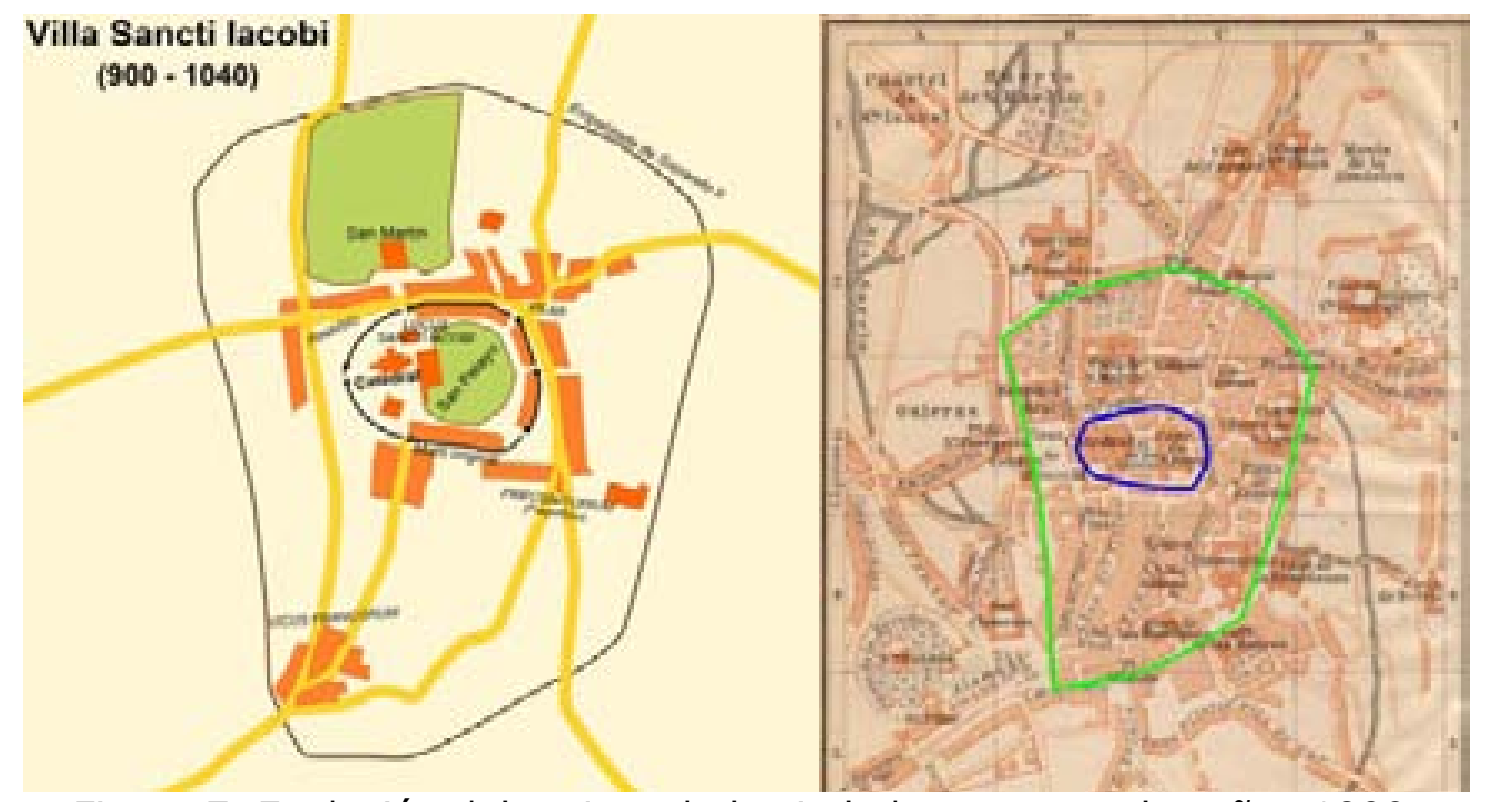

Figura 7. Evolución del recinto de la ciudad, en torno a los años 1000 y 1900.

La ciudad fue destruida el 10 de agosto del año 997 por Almanzor, que sólo respetó el sepulcro del apóstol. Se emprendió enseguida la reconstrucción $y$, a mediados del siglo XI, el obispo Cresconio la dotó de fosos y de una nueva muralla construida sobre el antiguo anillo de empalizadas, para proteger los nuevos barrios que habían surgido más allá del Locus. Además, reivindicó para Santiago la condición de Sede Apostólica. A lo largo de los siglos XII y XIII se fue articulando, dentro del recinto amurallado, la red de calles que hoy perdura. En la época del arzobispo Diego Gelmírez se consiguió la categoría de iglesia metropolitana (1120). Su autoridad alcanzaba a 
la mayor parte de las diócesis del naciente reino de Portugal y se imponía sobre la mayoría de las de León. Unas últimas noticias sobre el templo antes de volver al texto de Picaud: la coronación por Diego Gelmírez de Alfonso Raimúndez, el futuro Alfonso VII, el Emperador, como rey de Galicia tuvo lugar en la catedral compostelana en 1111; el temprano levantamiento burgués contra Gelmírez y la reina Urraca en 1117 dio lugar a destrozos que en parte nos van a complicar el reconocimiento de la Puerta de Platerías; en 1181 se produjo la concesión del privilegio del Año Santo Jubilar Jacobeo mediante la bula Regis Aeterni del papa Alejandro III.

\section{La catedral}

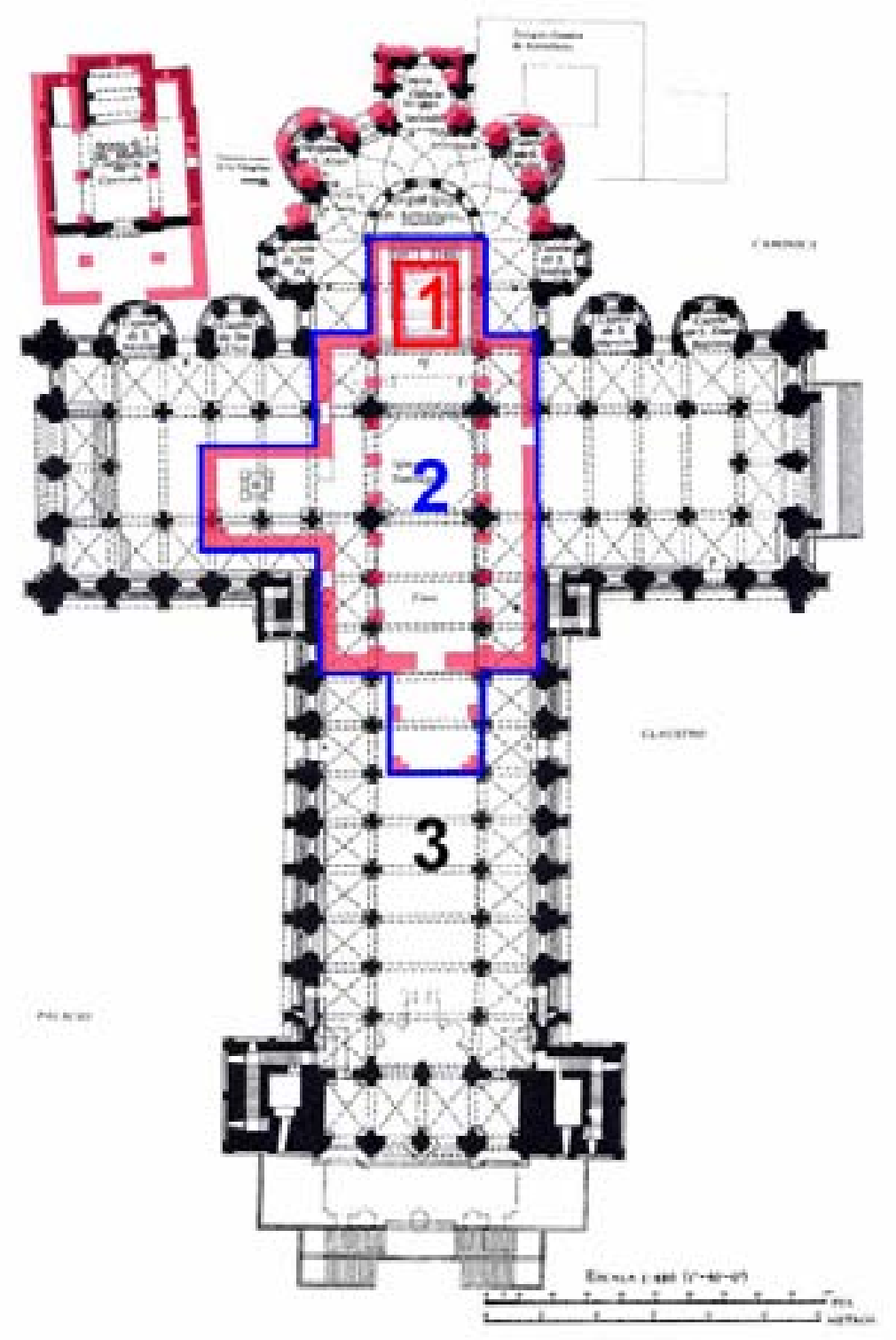

Figura 8. Evolución de la planta del santuario:

1) Alfonso II; 2) Alfonso III; 3) Catedral románica. 
La tumba del Apóstol es un mausoleo rectangular, originariamente de dos pisos, hecho de sillares de gran tamaño dispuestos a soga y tizón, que hoy queda bajo el altar mayor de la catedral (figura 9).

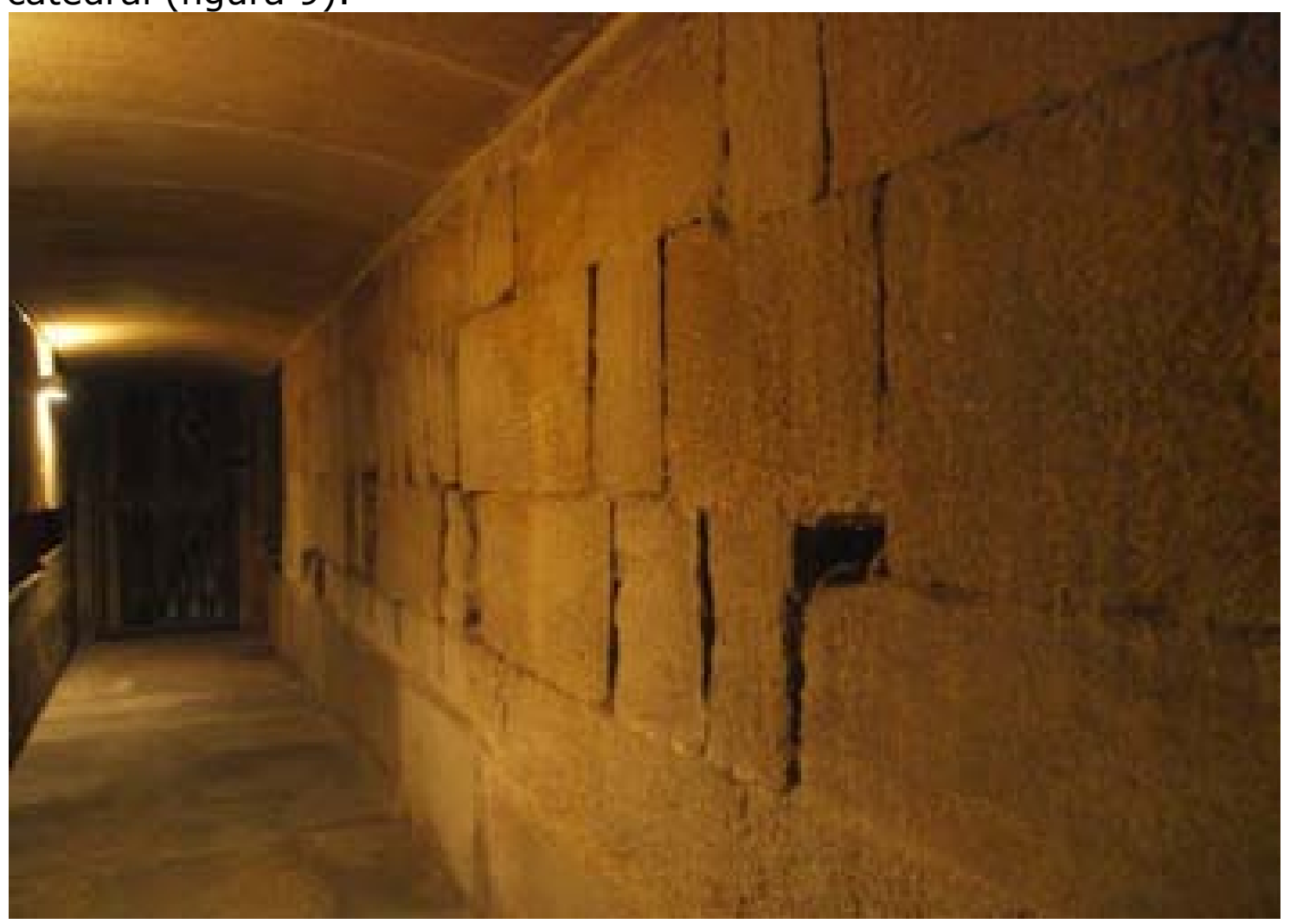

Figura 9. Pared externa del sepulcro.

Alfonso II el Casto, rey de Asturias, había levantado en torno a ella un primer templo, de pequeño tamaño. En el año 899 el rey Alfonso III edificó una nueva basílica más grande, de tipo visigodo, que mantenía la posición original del enterramiento. En el año 1075 el obispo Diego Peláez dio comienzo a la construcción de la catedral románica (figura 8 ). Picaud dice de ella, hacia el final del capítulo IX:

Desde el comienzo de la obra hasta nuestros días, este templo florece con el resplandor de los milagros de Santiago, pues, en él se concede la salud a los enfermos, se restablece la vista a los ciegos, se suelta la lengua de los mudos, se franquea el oído a los sordos, se da movimiento libre a los cojos, se concede liberación a los endemoniados $y$, lo que es todavía más, se atienden las preces del pueblo fiel, se acogen sus ruegos, se desatan las ligaduras de los pecados, se abre el cielo a los que llaman a sus puertas, se consuela a los afligidos, y las gentes de todos los países del mundo allí acuden en tropel a presentar sus ofrendas en honor del Señor. 
Es un párrafo importante porque, ¿qué movía a los peregrinos a ponerse en viaje? José Ángel García de Cortázar (1994) considera como razón principal la búsqueda de un milagro, gracias al contacto con la reliquia del santo intercesor. Otros motivos son: 1) el deseo de purificación por medio del desarraigo físico, que incluye una promesa, el cumplimiento de un voto formulado en circunstancias difíciles, el anhelo de la remisión de los pecados, la imploración y la acción de gracias, el cumplimiento de una penitencia, etc.; en definitiva, la búsqueda de la salvación, el que debería ser el motivo primordial; 2) el cumplimiento de una sentencia judicial, y 3) el cumplimiento de un encargo a cuenta de otro (Bravo Lozano 1989: 8).

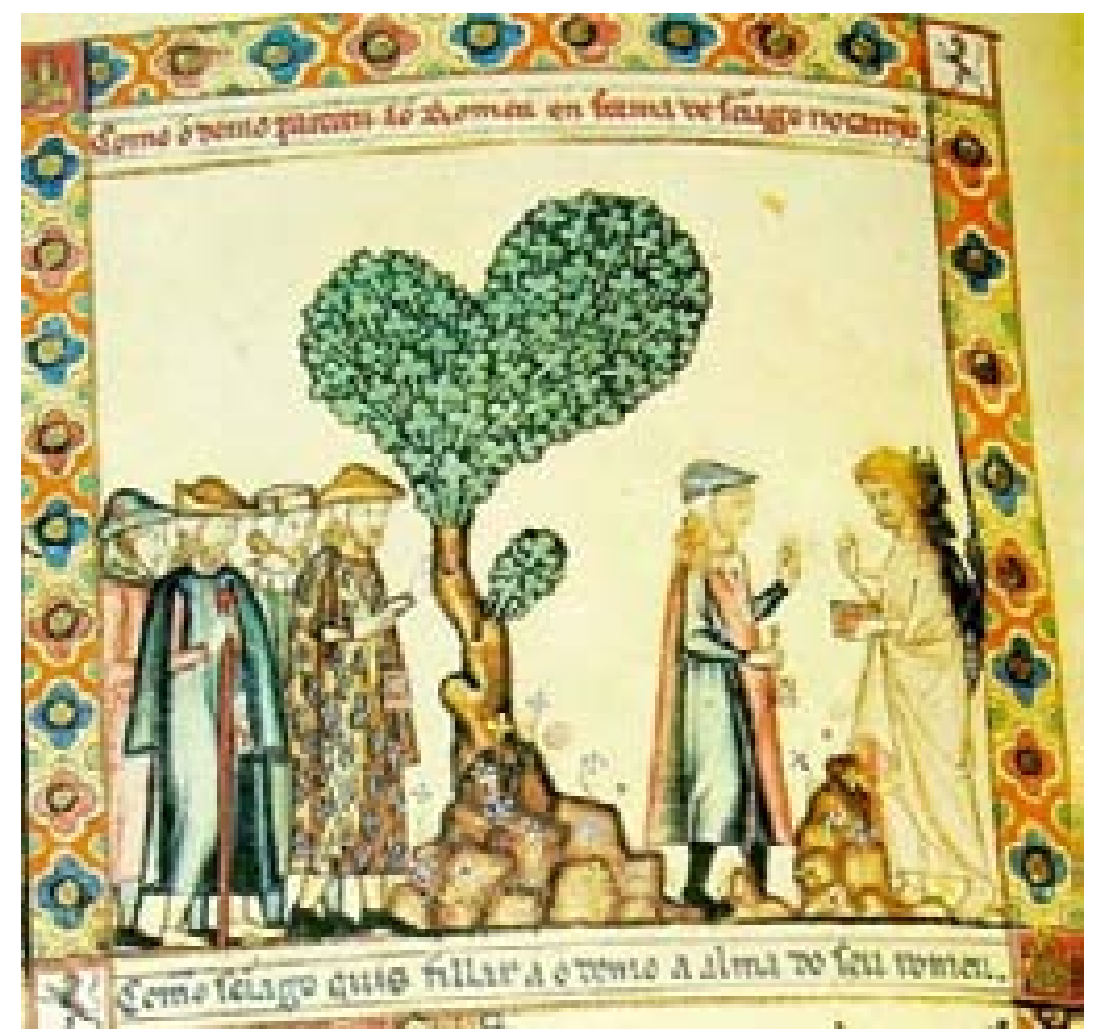

Figura 10. Miniatura de las Cantigas.

El peregrino debía de tener sus buenas razones para arrostrar los peligros del viaje. En esta ilustración de las Cantigas, el demonio, disfrazado de Santiago, sale al paso del peregrino para engañarle. En el texto de la parte superior se puede leer: "Como o demo pareceu ao romeu en forma de Santiago no camyo" (figura 10).

Sin embargo, precisamente en este contexto de apogeo del camino, un coetáneo, San Anselmo de Canterbury, preconizaba otra vía de ascesis contraria a estas peregrinaciones: el desarraigo respecto a los lugares se sustituye por el desapego de las cosas. Las oraciones y meditaciones de San Anselmo expresan la interiorización 
de Dios, cómo el hombre ha de albergarlo y convertirse en su santuario. Basta con refugiarse en el interior del alma, con desasirse del mundo, con estimar que la vida terrena es, simplemente, una via hacia el cielo por la que el hombre peregrina. No será entonces necesaria la sufrida peregrinación a Santiago, Jerusalén o Roma, o a cualquiera de los innumerables santuarios que jalonan la geografía de la Cristiandad. Porque -volviendo de nuevo a Picaud- si lo que se quiere son reliquias, ¿para qué ir tan lejos, estando toda Europa cuajada de santuarios que las custodian? Precisamente el capítulo VIII está dedicado a los muchos santuarios que marcan las etapas del Camino.

A lo largo del capítulo IX, Picaud describe las grandes dimensiones y estructura del edificio, pétrea ciudad espiritual que se sigue elevando hoy día sobre la ciudad profana que la rodea. La propia basílica constituye un tercer documento - "orientado" como buena iglesia, con la cabeza mirando a Oriente como el mapa del Beato- que se puede cotejar con la descripción de Picaud. Es un documento colosal que, como hemos visto, trasciende las tres dimensiones de su materialidad puesto que participa de lo trascendente. La descripción de Picaud se vale de un sistema de medición antropométrica, eco del sistema vitrubiano:

La basílica de Santiago tiene de longitud 53 alzadas de hombre, a saber, desde la puerta occidental hasta el altar del Salvador. De anchura, en cambio, es decir, desde la Puerta Francesa hasta la del mediodía, tiene 39. Su longitud y anchura por fuera no hay quien pueda saberlo. La iglesia en sí consta de nueve naves en la parte inferior, y seis en la superior y una capilla mayor, en la que se halla situado el altar del Salvador, y una girola y un cuerpo y dos brazos, y otras ocho capillas pequeñas más, cada una con su respectivo altar. Hemos de explicar que de las nueve naves, seis son pequeñas y tres grandes. La primera nave, la principal, va desde la puerta occidental hasta los pilares centrales, que en número de cuatro, sustentan toda la iglesia, y tiene una navecita a la derecha y otra a la izquierda. Las otras dos naves grandes se hallan en los dos brazos: la primera se extiende desde la Puerta Francesa hasta los cuatro pilares del crucero de la iglesia; y la segunda, desde los mismos pilares hasta la puerta meridional. Estas dos naves tienen a su vez dos navecillas laterales. 


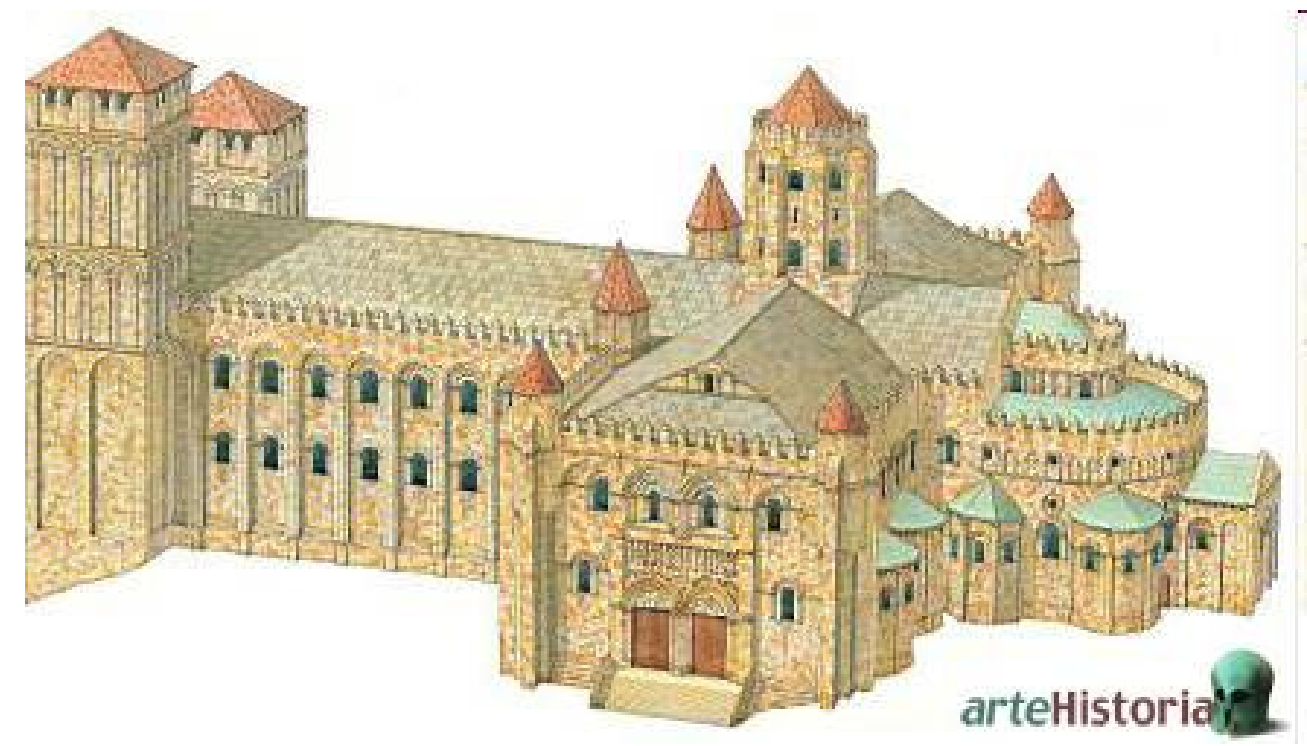

Figura 11. Reconstrucción del aspecto original de la catedral desde el lado Sur: vista desde abajo su mole se antojaba una ciudad bien guardada con almenas y torres.

La de Santiago es lo que llamamos una "iglesia de peregrinación", con naves laterales y tribunas sobre ellas, y deambulatorio con absidiolos radiales en torno al ábside (girola). Está pensada para la circulación interna de los peregrinos, que pueden recorrer todo el recinto del edificio sin molestar la celebración de la misa, alrededor de la capilla mayor, el presbiterio y la nave central. Los peregrinos pueden visitar las capillas del transepto y la girola, rezar, oír misa y rendir culto a las reliquias, y acercarse, por la parte trasera del altar, a la capilla de la Magdalena, para orar junto a la pared de la estancia que guarda el cuerpo santo. Se parece a las iglesias francesas de Saint-Martin de Tours, Saint-Martial de Limoges, Sainte-Foy de Conques y Saint-Sernin de Toulouse. No obstante, a pesar de que comparten en mayor o menor medida casi todas estas soluciones funcionales, en las últimas décadas se ha puesto en duda que estos edificios correspondan a una supuesta misma "escuela".

Las tres naves principales alcanzan hasta el techo de la iglesia, mientras que las seis pequeñas alcanzan sólo hasta las medias cimbras. Las naves grandes tienen todas ellas una anchura de once alzadas y media de hombre. Hemos de explicar que una alzada de hombre son justos ocho palmos. 


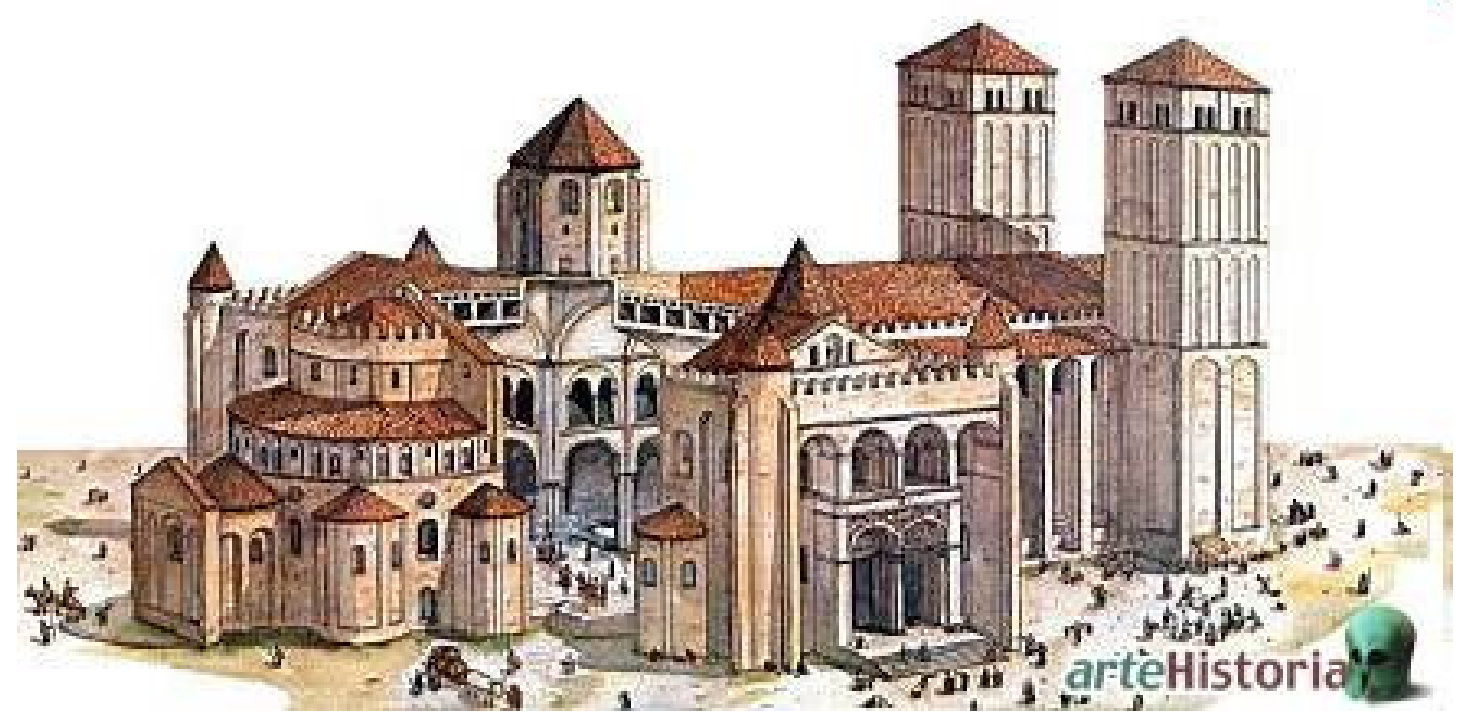

Figura 12. Reconstrucción desde el Noreste.

Se alternan rítmicamente pilares cruciformes de fuste y basa cuadrangular, con semicolumnas adosadas, con otros cruciformes de sección y basa circular, con semicolumnas adosadas, variación característica de la estética románica.

En esta iglesia no hay grieta ni defecto alguno; está magníficamente construida, es grande, espaciosa, luminosa, armoniosa, bien proporcionada en anchura, longitud y altura, y de admirable e inefable fábrica.

Enorme, armoniosa y sólida, es la imagen de la Jerusalén Celestial, como confirmará más adelante el Pórtico de la Gloria, que Picaud no llegó a conocer. También parece reconocerse en ella el modelo del Templo de Salomón, al que toda catedral que se precie aspira a parecerse:

Además, tiene doble planta como un palacio real. Quien recorre por arriba las naves del triforio, aunque suba triste, se vuelve alegre y gozoso al contemplar la espléndida belleza del templo. 


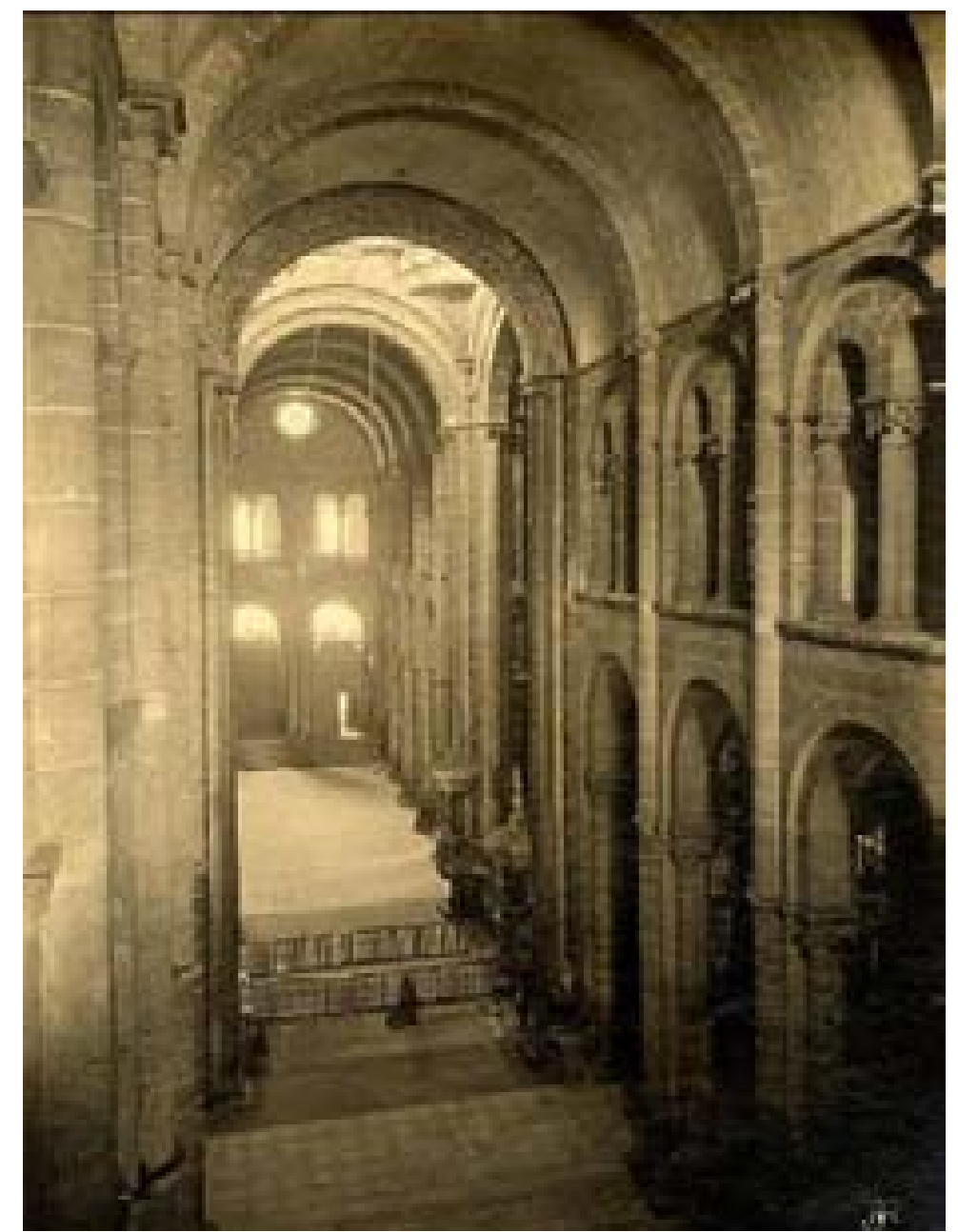

Figura 13. Interior desde las tribunas del transepto.

El conjunto está totalmente abovedado (figura 13): la nave central, con bóveda de cañón dividida por arcos fajones que van marcando los tramos; las laterales, con bóveda de arista; y las tribunas, con una bóveda de cañón sobre la que se alza una segunda más alta de cuarto de cañón. Esta estructura sobre pilares y muros de exteriores se refuerza con contrafuertes enmarcados en grandes arcadas ciegas. Dos pisos de ventanas proporcionan luz indirecta a la nave central:

Las vidrieras que hay en la catedral alcanzan el número de 63. Sobre cada uno de los altares del ábside, hay tres. En cambio, en el cielo de la basílica, en torno al altar de Santiago, hay cinco vidrieras por las que el altar del Apóstol recibe una intensa iluminación. Y arriba, en el triforio, el número de vidrieras alcanza 43.

El simbolismo de la luz es claro, y pronto sería multiplicado por la arquitectura gótica, hasta el punto de que la propia catedral de Santiago corrió el peligro de ver sustituida su cabecera románica por otra gótica, más amplia y luminosa, cuyos cimientos se han 
encontrado bajo la escalinata de la Quintana (Muñoz Jiménez 2010: 444). Por su parte, la altura de las torres transmite de inmediato una tensión ascendente, y evoca la imagen de la ciudad fuerte y bien defendida (figura 11).

Como explica Picaud, "Nueve torres habrá en este templo", todas cuadradas salvo la del cimborrio: "dos sobre el pórtico de la fuente, otras dos sobre el pórtico meridional". Estas últimas son pequeñas torres de escalera, situadas en los ángulos salientes del transepto, las cuales culminan en cuerpos cilíndricos coronados por chapiteles cónicos, a la manera de las torres del Poitou (Notre-Damela-Grande de Poitiers), habiéndose conservado tan sólo parcialmente la del lado sudoeste. "[...] otras dos sobre el pórtico occidental", continúa Picaud; estas son las de mayor tamaño y se construyeron a finales del siglo XII, por lo tanto, todavía no estaban cuando Picaud visitó Santiago; "otras dos sobre cada una de las escaleras de caracol", en la intersección entre el brazo mayor y el transepto, con un remate de sección poligonal, "y otra mayor sobre el crucero en el centro de la basílica", que fue remodelada en el siglo XV.

Gracias a ellas y a las demás bellísimas realizaciones, la catedral de Santiago resplandece con gloriosa magnificencia. Además, toda ella está construida de poderosos bloques vivos, grisáceos y de una gran dureza como el mármol, en su interior está decorado con diversas clases de pinturas, y por el exterior está muy bien cubierta con tejas y plomo. Sin embargo, de esta relación, unas cosas están terminadas y otras sin acabar.

En cuanto a los pórticos, escribe Picaud:

Tres pórticos mayores y siete pequeños tiene la iglesia: el primero, es decir, el principal, mira al poniente; el segundo, al mediodía, y el tercero al norte. En cada pórtico hay dos entradas, y en cada una de ellas dos puertas.

Son tres pórticos ilustrados por un mismo discurso iconográfico con el que Santiago se anticipa al esquema que caracterizará a las catedrales góticas francesas a partir de Chartres. Dedicada al Salvador, como es propio de las catedrales románicas (igual que las góticas se consagrarán a la Virgen), sus tres portadas desarrollaban un programa de la historia del género humano con sus capítulos dedicados a la caída y promesa de redención en la puerta Norte (el Génesis), su cumplimiento en la puerta Sur (la Redención), y el Juicio y Triunfo de Cristo (la Gloria) en la occidental (Martín González 1974: 441). En dicha articulación vemos también la proyección de las funciones del templo hacia el entramado urbano:

El Paradisus, en la plaza de la Azabachería, al Norte, una emulación del Paraíso de la basílica paleocristiana de San Pedro del 
Vaticano (amplio atrio porticado con una pila de agua en medio cubierta por un baldaquino), era el acceso de los peregrinos, con su mercado, y también constituía el marco de los ritos penitenciales.

Al Sur, Platerías, la puerta del obispo, también con su plaza abierta a la ciudad para la celebración de juicios y entradas triunfales.

La fachada occidental era posiblemente un espacio litúrgicosimbólico heredero de la tradición de los Westwerke carolingios (anteiglesia de uso secular que también podemos relacionar con el modelo del templo de Salomón). Además, la iglesia tenía otros siete pórticos menores.

\section{El pórtico Norte}

Empecemos por el acceso Norte (figura 14). La fuente que describe Picaud a continuación es un elemento frecuente en los santuarios, aunque en este caso no sea milagrosa ni medicinal:

Cuando nosotros, los de nación francesa, queremos entrar en la basílica del Apóstol, lo hacemos por la puerta septentrional. Delante de esta entrada, junto al camino, se halla el hospital de peregrinos pobres de Santiago, y a continuación, al otro lado de la calle, hay un atrio del que se baja por 9 peldaños. Al concluir la escalera de este atrio, hay una admirable fuente que no tiene pareja en todo el mundo. Se asienta esta fuente sobre tres escalones de piedra, que sostienen una hermosísima taza de piedra de forma circular, y cóncava, a manera de cubeta o cuenco, de tal tamaño que yo calculo que pueden bañarse cómodamente en ella quince personas. En su centro reposa una columna de bronce, de forma base heptagonal y de una altura proporcionada. De su remate salen cuatro leones, que echan por la boca cuatro chorros de agua, para refrigerio de los peregrinos y de los habitantes de la ciudad. Los chorros que salen de las fauces de los leones caen a la taza, que desagua en forma subterránea por un orificio perforado en ella. Y así ni se ve de dónde viene el agua ni adónde va. Es un agua dulce, nutritiva, sana, clara, magnífica, templada en invierno y fresca en verano. 


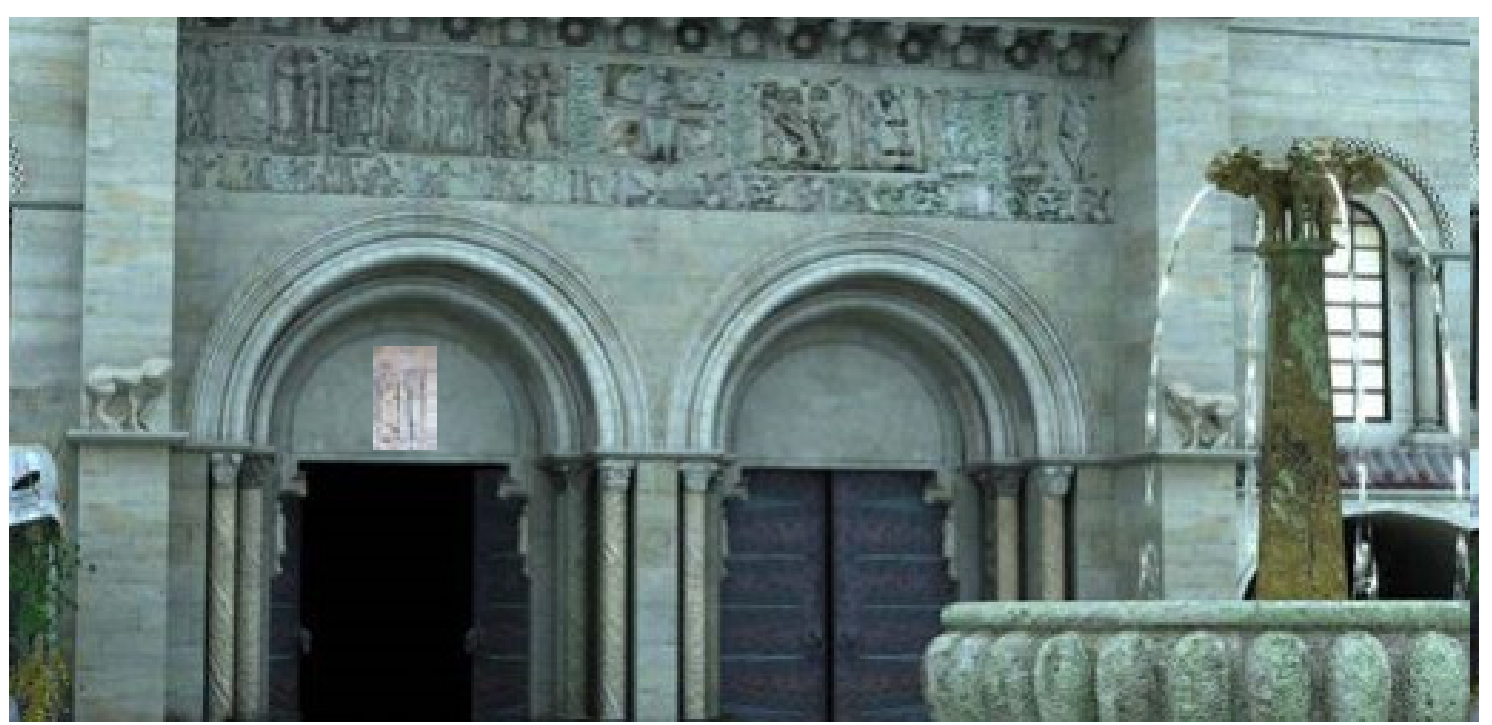

Figura 14. Reconstrucción del desaparecido pórtico Norte con la fuente del Paraíso.

Hoy día el vaso de la fuente se conserva en el claustro. Coronada entonces por cuatro leones, a la manera de los cuatro ríos del Paraíso, centraba un verdadero locus amoenus al que miraba el frontispicio de la fachada que vamos a estudiar, que poseía hermosas lastras con decoración vegetal junto a relieves historiados con el ciclo de la Caída de Adán y Eva. Un perfecto escenario para la celebración de los ritos penitenciales del Miércoles de Ceniza, propios de un centro de peregrinación.

\section{EL PARAÍSO DE LA CIUDAD}

Detrás de la fuente está, según dijimos, el paraíso, pavimentado de piedra, en el que, entre los emblemas de Santiago, se venden las conchas a los peregrinos. Se venden allí también botas de vino, zapatos, mochilas de piel de ciervo, bolsas, correas, cinturones y hierbas medicinales de todo tipo y demás especias, así como otros muchos productos. Los cambistas, mesoneros y otros mercaderes están en la rúa Francígena. La extensión del paraíso es de un tiro de piedra por cada lado. 


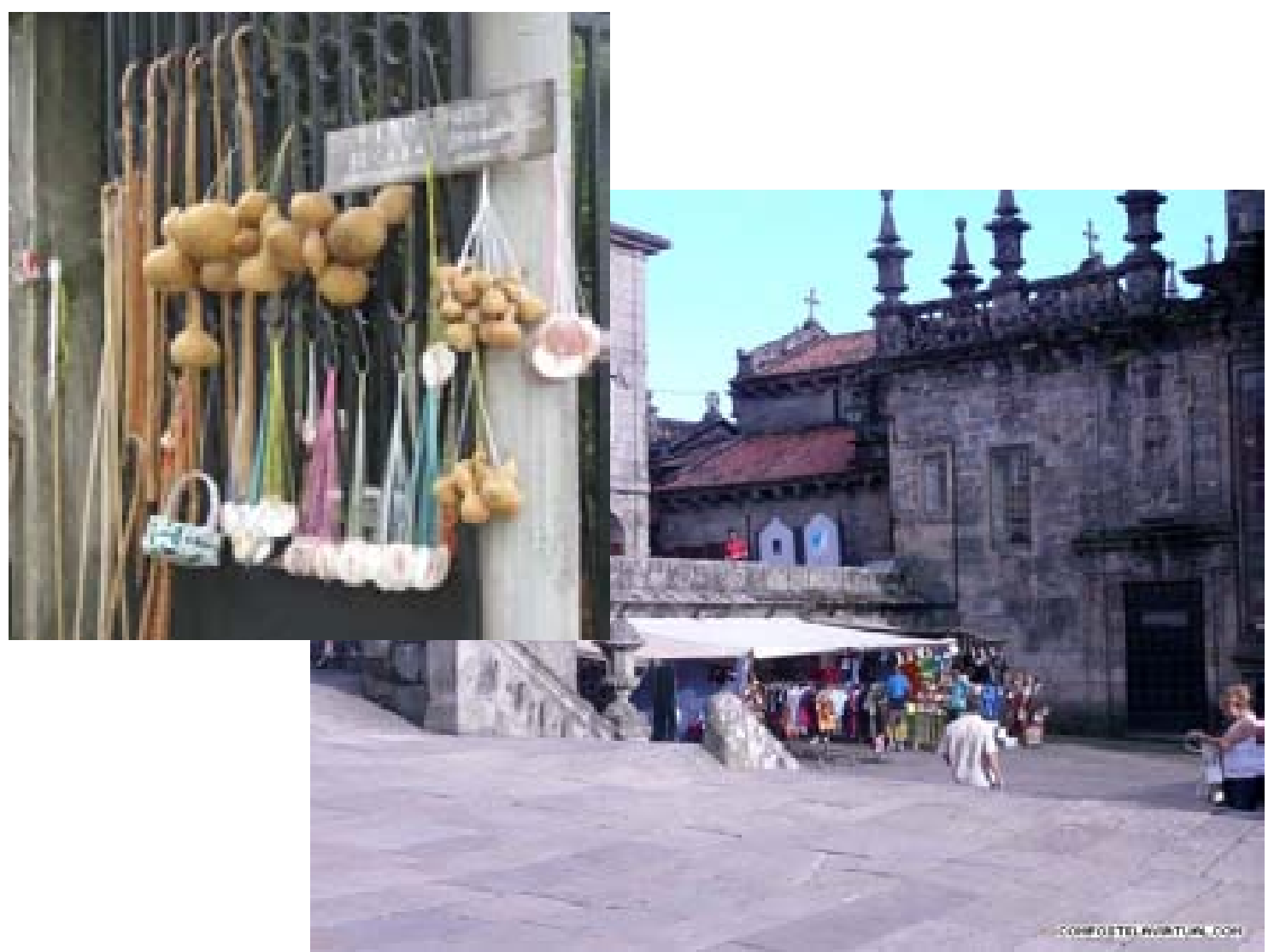

Figura 15. Comercio en torno a la plaza de la Azabachería.

Muy posiblemente las obras de la puerta Norte se realizaron contemporáneamente a las de Platerías, entre 1100 y 1112 . El texto de Picaud describe una fachada que ya no existe, porque un incendio la destruyó en 1757 y fue sustituida por otra barroca. No obstante buscaremos las piezas que han sobrevivido, reubicadas en otros sitios. Aymeric Picaud se basa en notas que tomó durante su peregrinación y en sus recuerdos, por lo que, como veremos ahora, es posible que sufriera algunas confusiones:

Detrás de este atrio (paraíso), está la puerta septentrional o Francígena de la basílica de Santiago, en la que hay dos entradas, también hermosamente labradas con los siguientes elementos: en cada una de las dos entradas, por la parte de fuera, hay seis columnas, unas de mármol y otras de piedra, tres a la derecha y tres a la izquierda, es decir, seis en una entrada y seis en la otra, lo que en total hace doce. Sobre la columna adosada al muro que por la parte de fuera separa los dos pórticos, está sentado el Señor en trono de majestad, impartiendo la bendición con la derecha y con un libro en la izquierda. Rodeando el trono, y como sosteniéndolo, aparecen los cuatro evangelistas [figura 16]; a su derecha está representado el paraíso, donde el Señor vuelve a aparecer reprendiendo por su pecado a Adán y Eva; y a la izquierda, en otra representación, expulsándolos del paraíso [figura 17]. 
ETAYO GORDEJUELA, Miguel (2011): "La representación artística de la ciudad de Santiago. Leyendas y escrituras" [en línea]. En: Ángulo Recto. Revista de estudios sobre la ciudad como espacio plural, vol. 3, núm. 1, pp. 135-173. En: http://www.ucm.es/info/angulo/volumen/Volumen03-1/varia04.htm. ISSN: 1989-4015

http://dx.doi.org/10.5209/rev_ANRE.2011.v3.n1.195[0

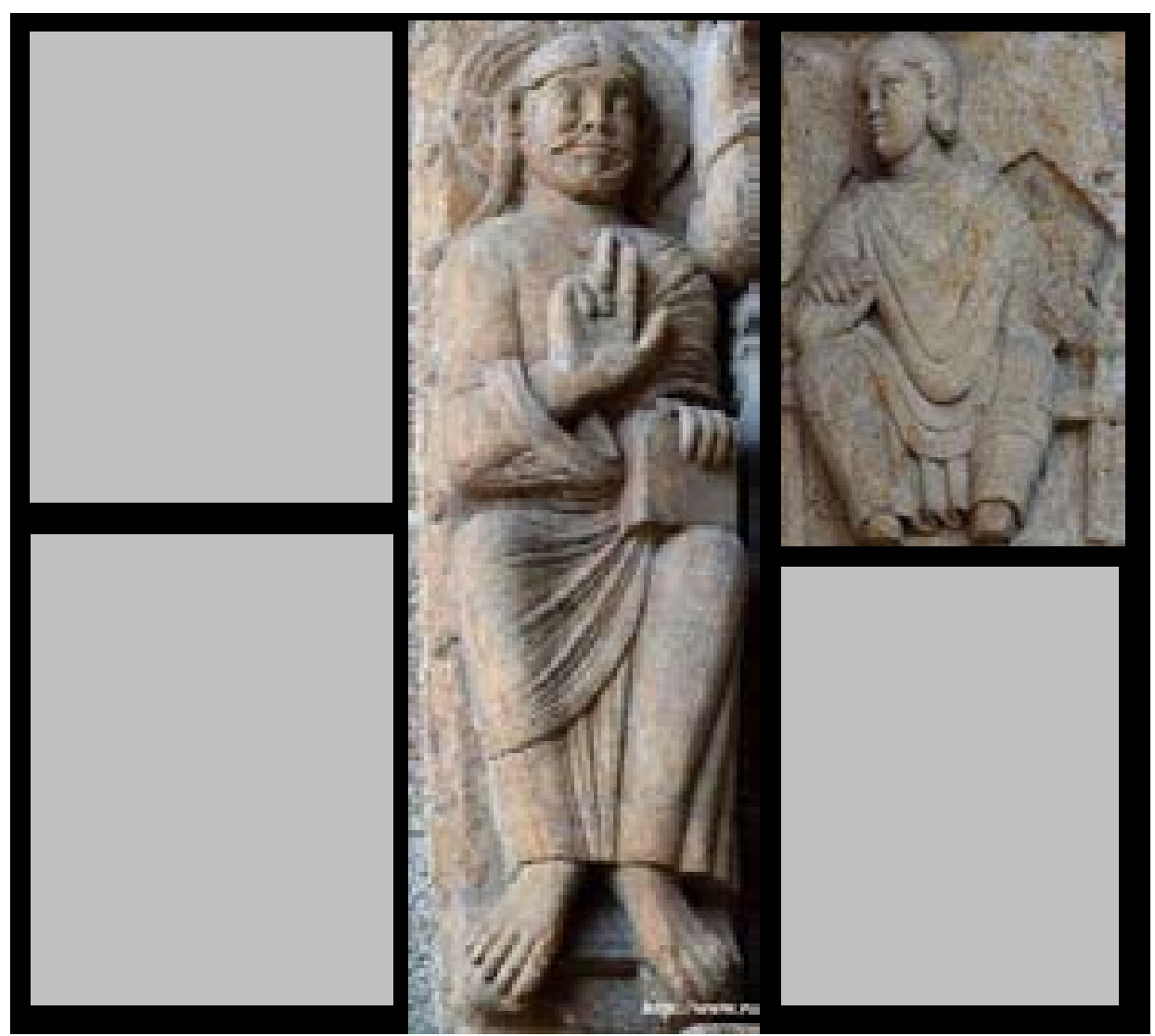

Figura 16. Pantocrátor y un elemento del Tetramorfos.

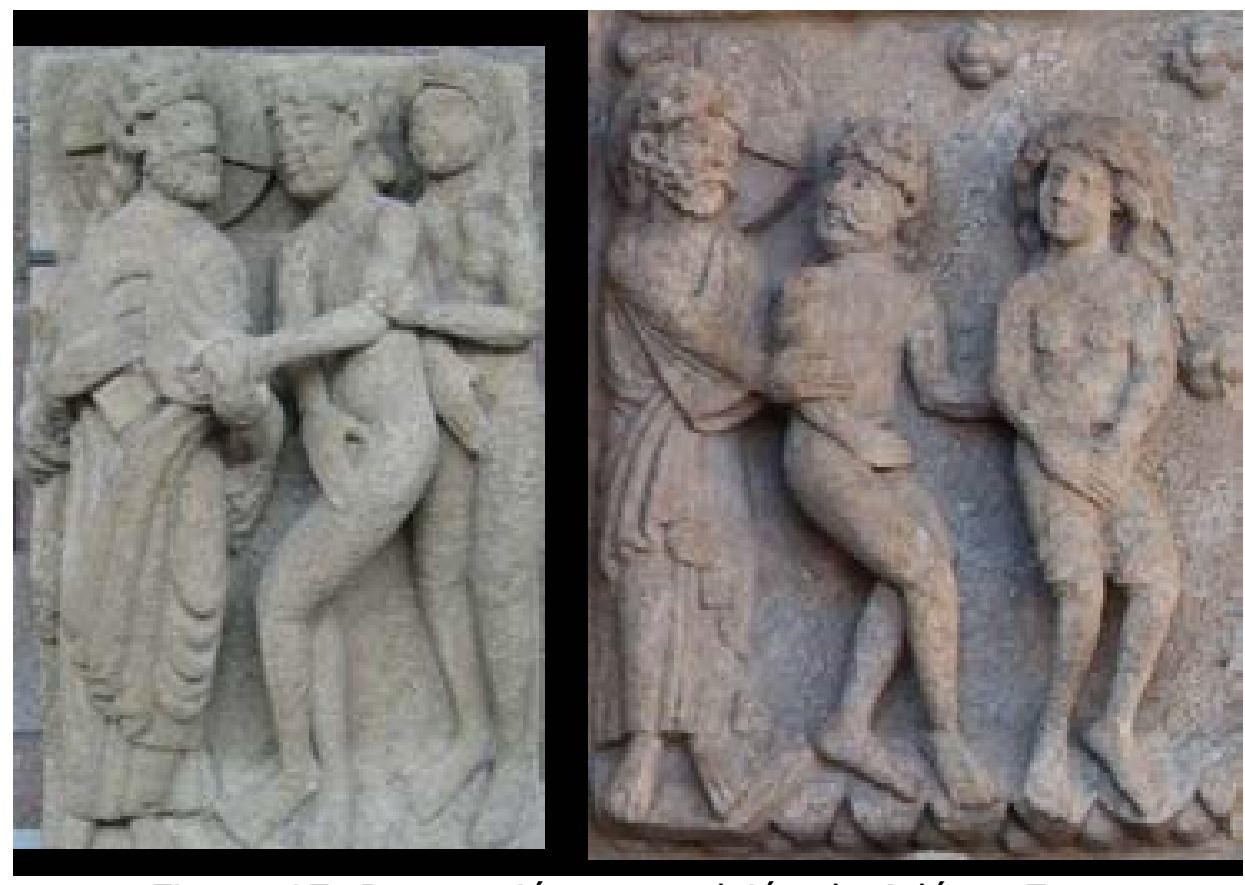

Figura 17. Reprensión y expulsión de Adán y Eva. 
Muy posiblemente, a ambos lados de este gran ciclo bíblico desarrollado en el frontispicio -al que también pertenecerían piezas como la Eva amamantando a Caín, la creación de Adán y la creación de Eva (figura 18) - se situaban lastras relativas a la promesa de redención: el sacrificio de Isaac, David músico vence al demonio, la Mujer del León (figura 19), la Mujer de las Uvas y, como cuenta Picaud más adelante, los meses, doce como los apóstoles.
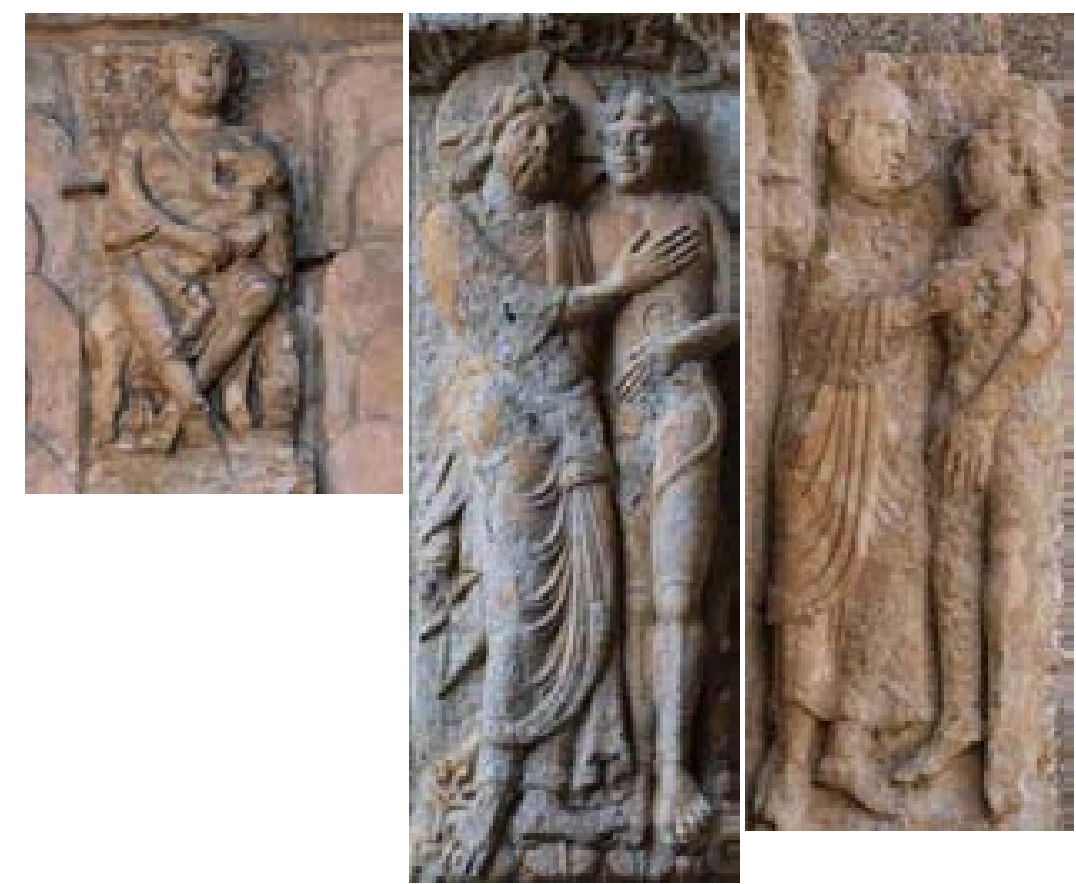

Figura 18. Eva amamantando a Caín, creación de Adán y de Eva.

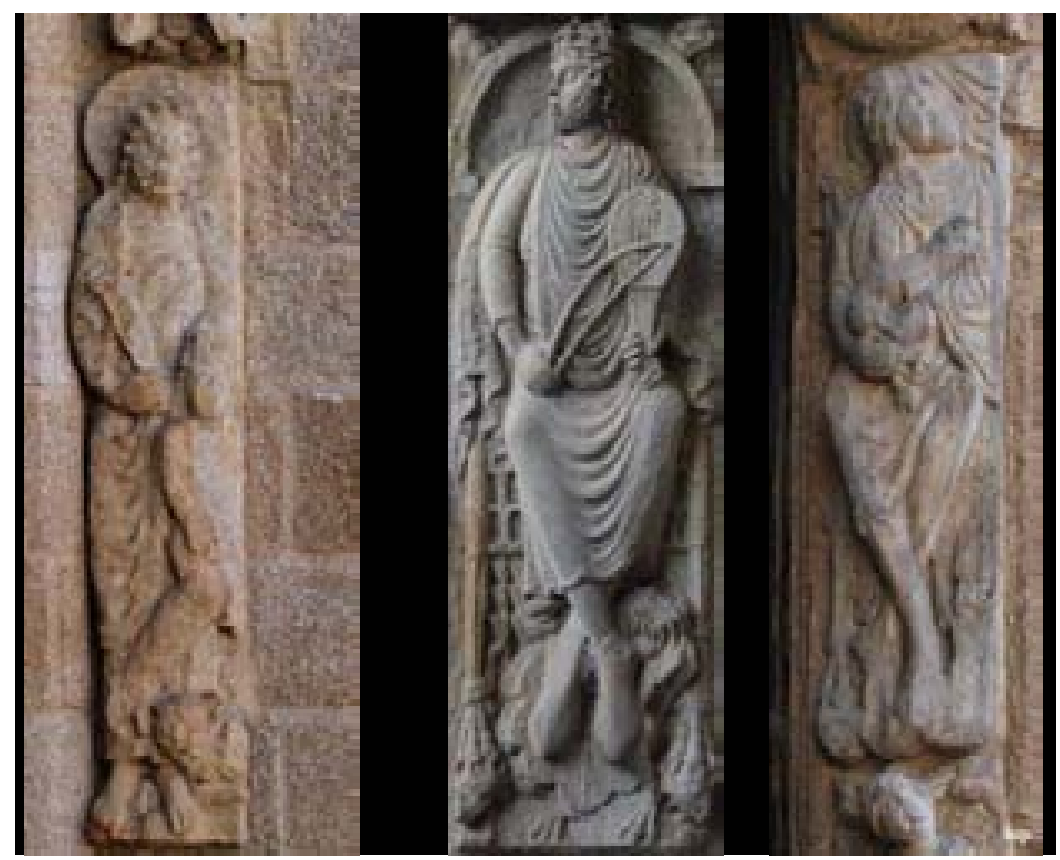

Figura 19. Sacrificio de Isaac, David músico y Mujer del león. 
Si la asociación entre el ciclo del Génesis y el de los Meses ofrecía la posibilidad de la redención del pecado a través del trabajo, la esperanza en la próxima venida del Mesías se expresaba a través de su prefiguración en las imágenes de David e Isaac. Por último, el contenido de este mensaje se hacía explícito en el relieve de la Anunciación (figura 20).

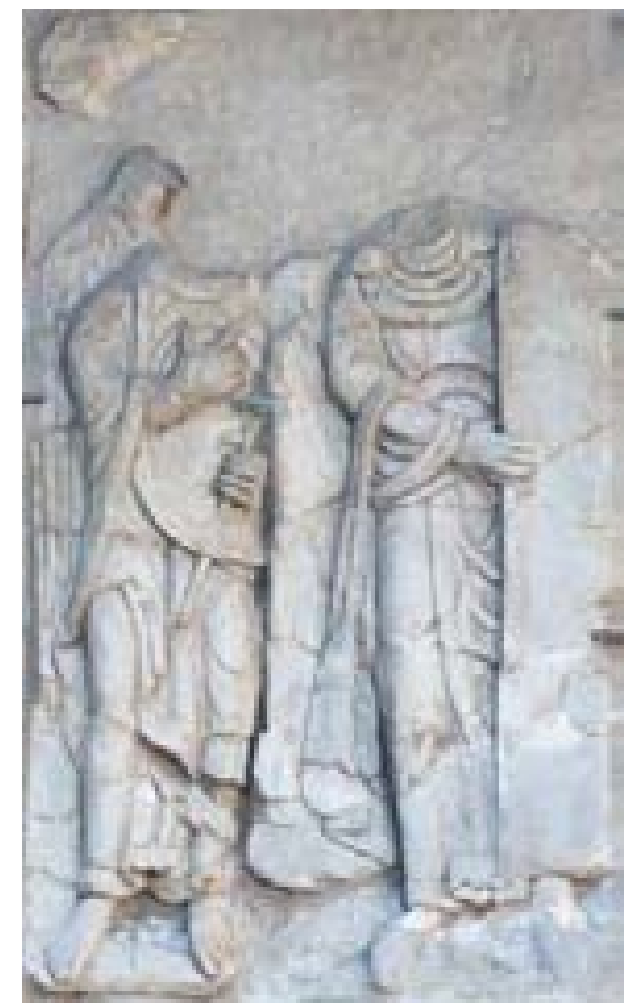

Figura 20. Anunciación.

Allí mismo hay representados por doquier innumerables imágenes de santos, bestias, hombres, ángeles, mujeres, flores y demás criaturas, cuyo significado y formas no podemos describir, por su gran número. Sin embargo, sobre la puerta de la izquierda, según entramos en la catedral, es decir, en el tímpano, está representada la anunciación de la bienaventurada Virgen María. Aparece también el ángel Gabriel dirigiéndole la palabra, a la izquierda de la entrada lateral, sobre las puertas, aparecen labrados los meses del año y otras muchas bellas representaciones. En las paredes, por la parte de fuera, aparecen dos enormes y feroces leones, uno a la derecha y otro a la izquierda, que miran siempre a las puertas en actitud vigilante. En las jambas, en la parte alta, aparecen cuatro apóstoles sosteniendo cada uno en su mano izquierda sendos libros y con las diestras elevadas impartiendo la bendición a los que entran en la catedral: en la puerta de la izquierda, a la derecha, está Pedro, y a la izquierda, Pablo; y en la puerta de la derecha, a la derecha, el apóstol Juan, y a la izquierda Santiago. Además sobre cada una de las cabezas de los apóstoles, aparecen esculpidas unas cabezas de toro que resaltan de los dinteles. 
Otras figuras que parecen corresponder a esta portada, seguramente situadas encima del arco de la puerta derecha, serían estas representaciones del pecado: el Centauro, la Sirena, el Ballestero y el Hombre que cabalga a un gallo (figura 21).

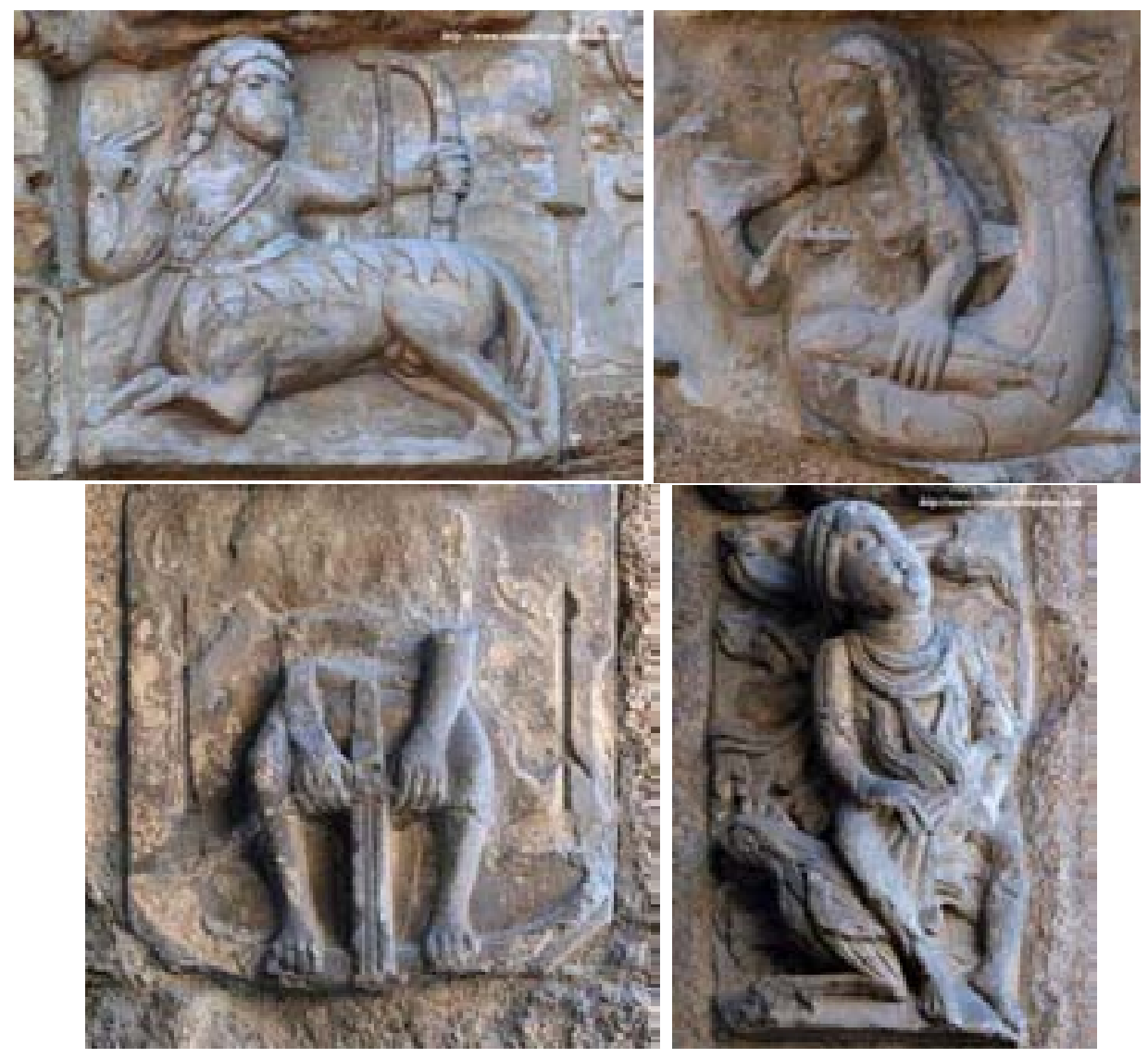

Figura 21. Centauro, Sirena, Ballestero y Hombre que cabalga un gallo.

De la ornamentación de esta primitiva porta francigena han llegado hasta nosotros numerosas piezas, algunas conservadas en el Museo de la Catedral (columnas entorchadas, Mes de Febrero, Mujer del Racimo de Uvas, Reprensión de Adán y Eva), y otras tantas reaprovechadas en la fachada meridional. 


\section{El pórtico Sur}

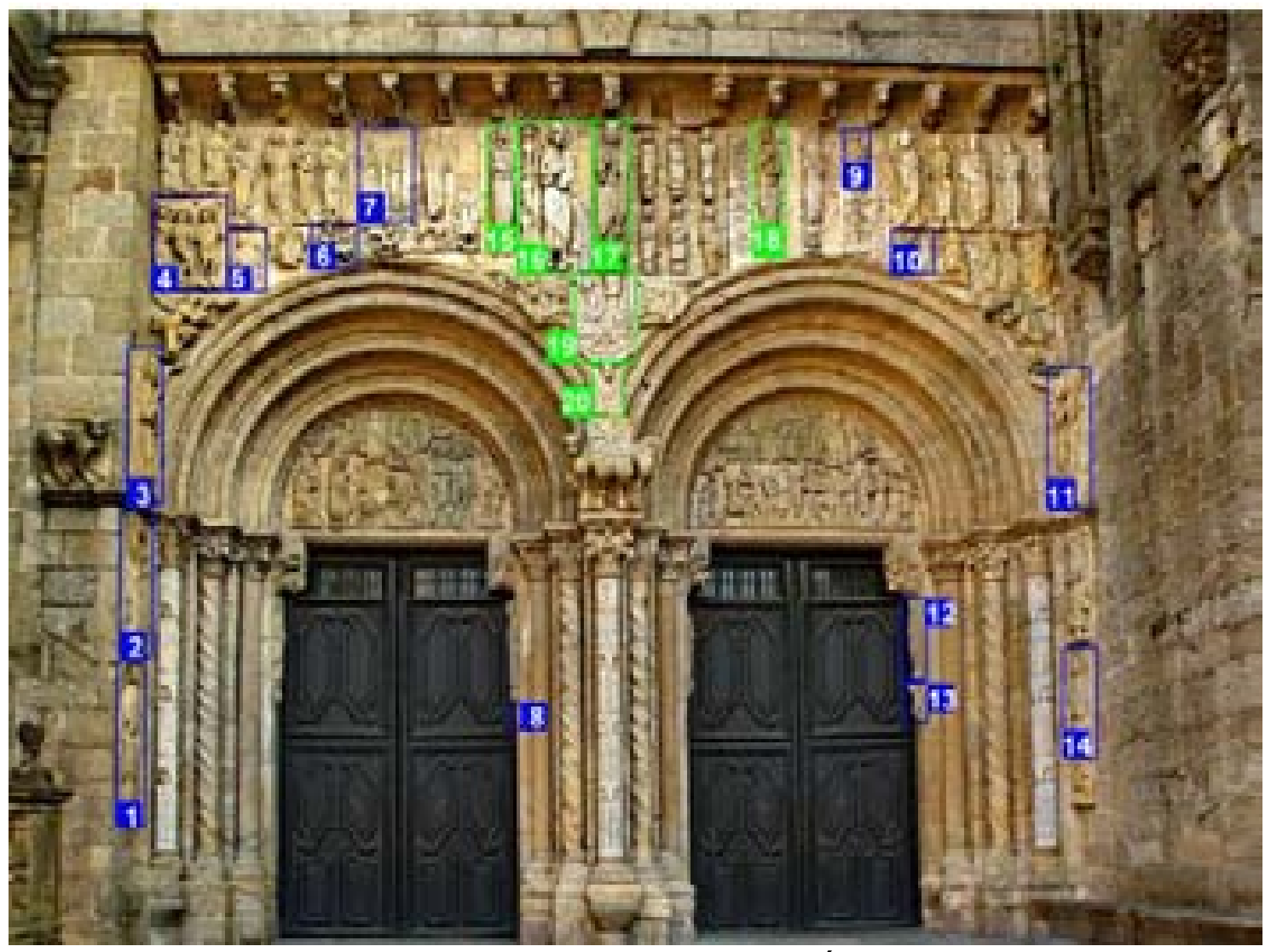

Figura 22. Aspecto actual de la Puerta de Platerías. En azul los elementos que pueden proceder del destruido Pórtico Norte: 1) David músico; 2) Creación de Adán; 3) Pantocrátor; 4) Expulsión de Adán y Eva; 5) San Mateo del Tetramorfos; 6) Centauro; 7) Anunciación; 8) Ballestero; 9) Eva amamantando a Caín; 10) Sirena; 11) Creación de Eva; 12) Mujer del león; 13) Hombre que cabalga un gallo; 14) Sacrificio de Isaac. En verde, los que parecen destinados al primitivo Pórtico Oeste: 15) San Andrés; 16) Santiago; 17) El Salvador; 18) Un apóstol; 19) Abraham saliendo de su tumba; 20) Demonio vencido.

Si en la puerta Norte se exponía la Caída y la promesa de redención, en la Sur se desarrollaba el tema del cumplimiento de esa promesa a través de la Vida de Cristo, en los tímpanos (Encarnación, Vida Pública y Pasión), y de los Apóstoles, en el friso. De relieve aún muy plano y ceñido al marco arquitectónico es la obra maestra del Maestro de Platerías o Maestro Esteban, que trabajó antes en San Isidoro de León, en Pamplona, desde 1101; en Santiago desde 1103 $\mathrm{y}$, probablemente después, en Toulouse y Moissac. Un incendio en 
1117, como comentábamos antes, debió afectar a esta fachada Sur; algunas figuras del primitivo pórtico Oeste, ya veremos por qué, se incorporaron a la puerta de Platerías; y en el siglo XVIII recibió también figuras de la portada Norte, lo que explica en parte su desorden y la mano de maestros diferentes. La portada de Platerías miraba hacia el palacio del obispo, destruido en la revuelta de los compostelanos. El nuevo palacio se erigiría luego en el lado norte.

La puerta meridional de la basílica del Apóstol tiene, como hemos dicho, dos entradas y cuatro hojas. En la entrada de la derecha, por la parte de fuera está esculpida, en primer término, de modo admirable, encima de las puertas, [Picaud lee de derecha a izquierda] el prendimiento del Señor. Allí se le ve atado a la columna a manos de los judíos, y azotado con correas, mientras Pilatos está sentado en su trono en actitud de juez.

La identificación de esta última figura es una confusión, pues la imagen representa la coronación de espinas. Picaud no menciona el Cireneo ni tampoco la curación del ciego, probable añadido que no corresponde al mismo estilo.

En la franja siguiente, encima de la anterior, aparece la bienaventurada Virgen María, Madre de Dios, con su Hijo en Belén, y los tres Reyes que vienen con su triple ofrenda a visitar al Niño y a la Madre, y la estrella y el ángel que los advierte de que no vuelvan al palacio de Herodes. En este tímpano de la derecha del espectador, por tanto, se muestra la naturaleza humana de Cristo [figura 23].

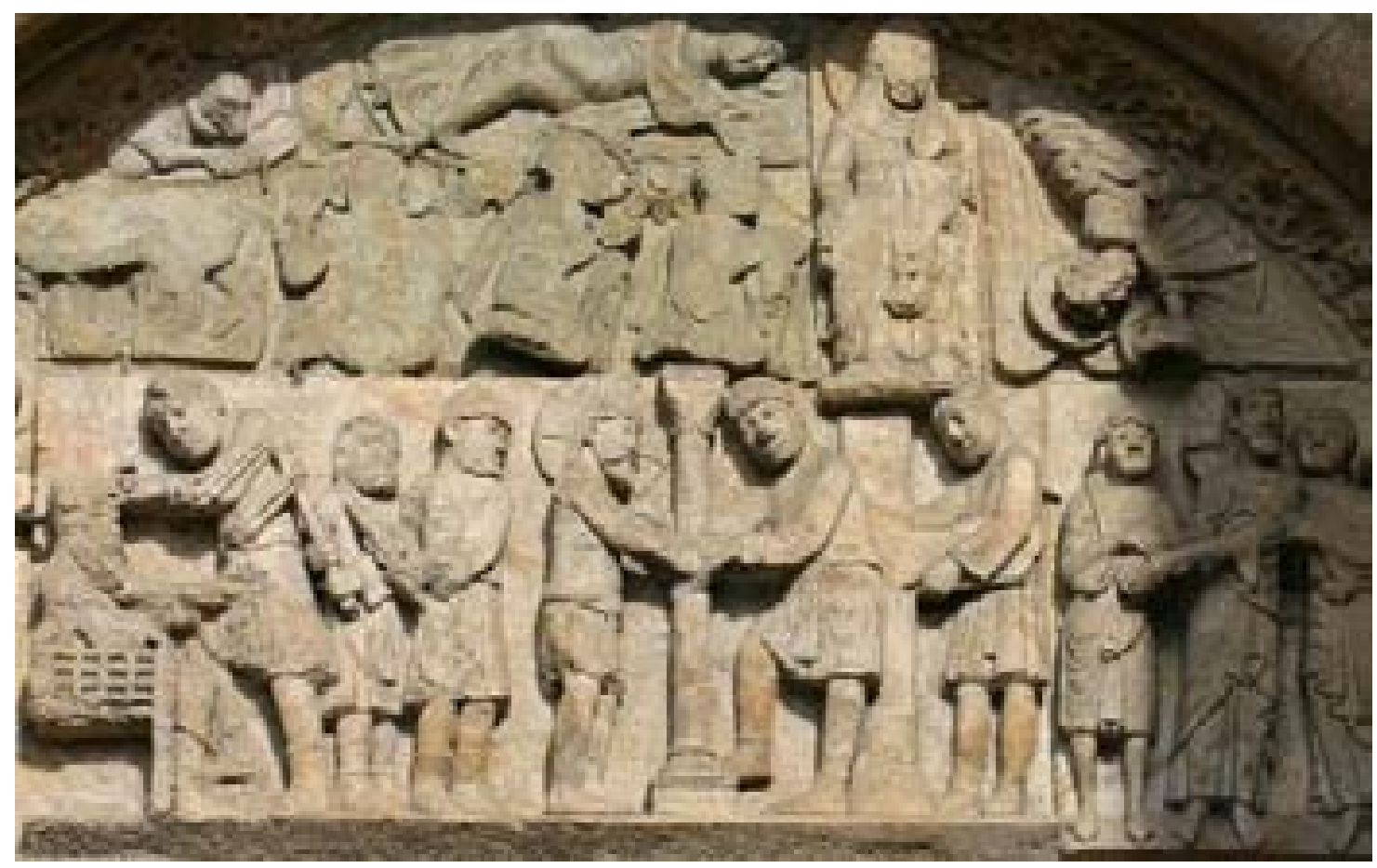

Figura 23. Tímpano derecho (según el espectador) de Platerías. 
En las jambas de esta entrada hay dos apóstoles, uno a la derecha y otro a la izquierda, como guardianes de las puertas. De igual manera en la entrada de la izquierda, también en las jambas, hay otros dos apóstoles.

En el tímpano de la izquierda en cambio, se nos muestra la naturaleza divina de Cristo, resistiendo frente a las tentaciones demoníacas y acompañado de una serie de ángeles, episodio que refleja su estancia en el desierto (figura 24):

En primer término de la misma entrada, sobre las puertas, están esculpidas las tentaciones del Señor. En efecto, ante el Señor aparecen unos horribles ángeles como monstruos, que le colocan sobre el pináculo del templo. Otros le presentan piedras incitándole a que las convierta en pan, mientras que otros le muestran los reinos del mundo insinuando que se los darán si postrándose los adora, icosa que Dios no quiera! Pero hay también otros ángeles blancos, es decir, buenos, a su espalda y por arriba, adorándole con incensarios.

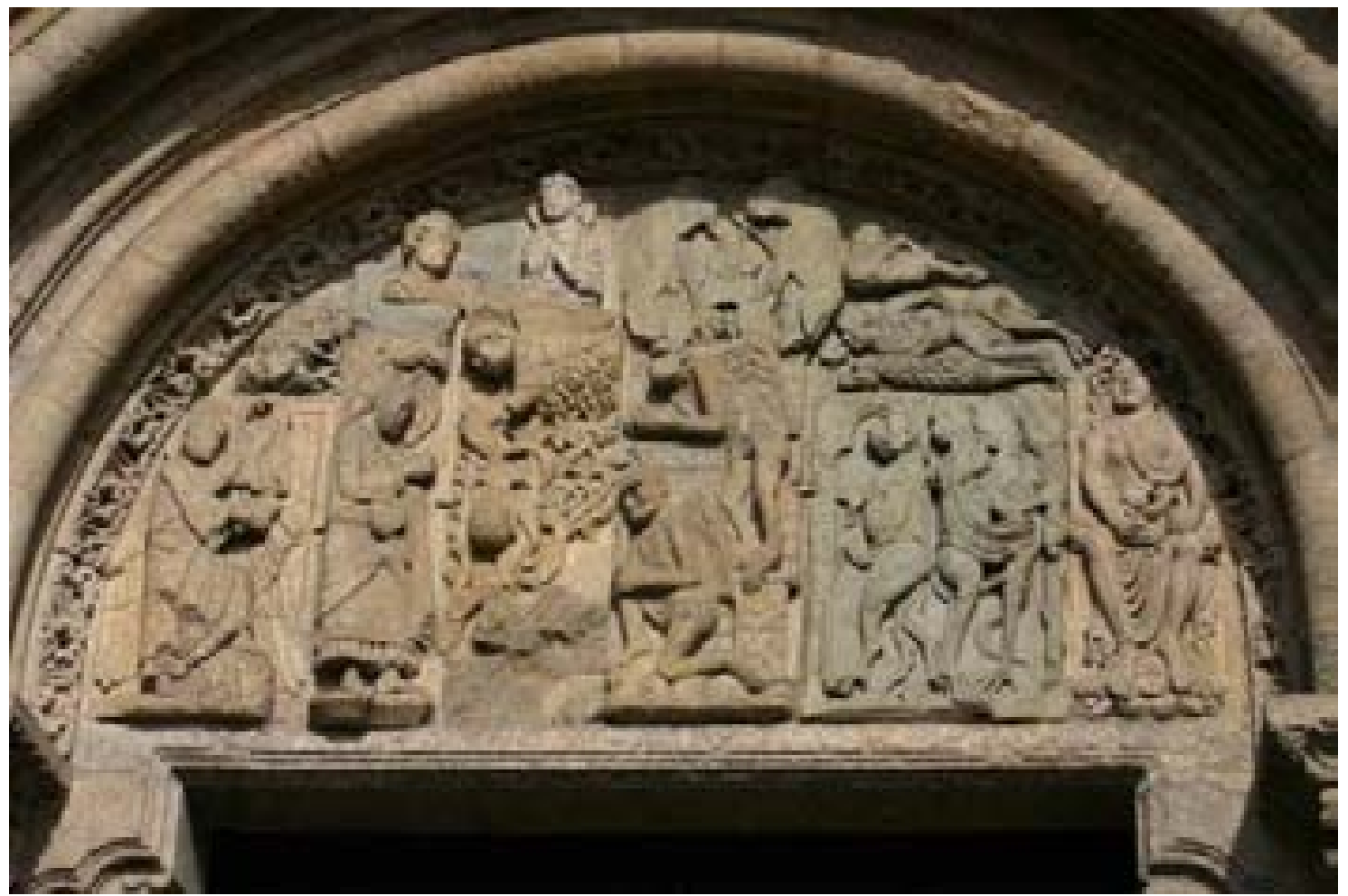

Figura 24. Tímpano izquierdo de Platerías.

En el mismo pórtico aparecen cuatro leones, uno a la derecha en una de las entradas, y otro a la izquierda en la otra. En la parte alta del pilar, entre las dos entradas, hay otros dos feroces leones, con las grupas apoyadas el uno contra el otro. 
Los tres leones que todavía hoy flanquean las dos entradas de Platerías, uno se ha perdido, seguramente por la construcción de la torre Berenguela (el cubo inferior data del siglo XIV); leones que simbolizan la justicia terrena como alusión al trono de Salomón, juez bíblico por excelencia.

En el mismo pórtico hay además once columnas: cinco a la derecha, a la entrada derecha; y cinco a la izquierda, en la entrada de la izquierda; mientras que la undécima está entre las dos entradas, dividiendo los ciborios. Estas columnas, unas de mármol y otras de piedra, tienen esculpidas bellas imágenes de flores, hombres, aves y animales. El mármol es de color blanco [figura 25].
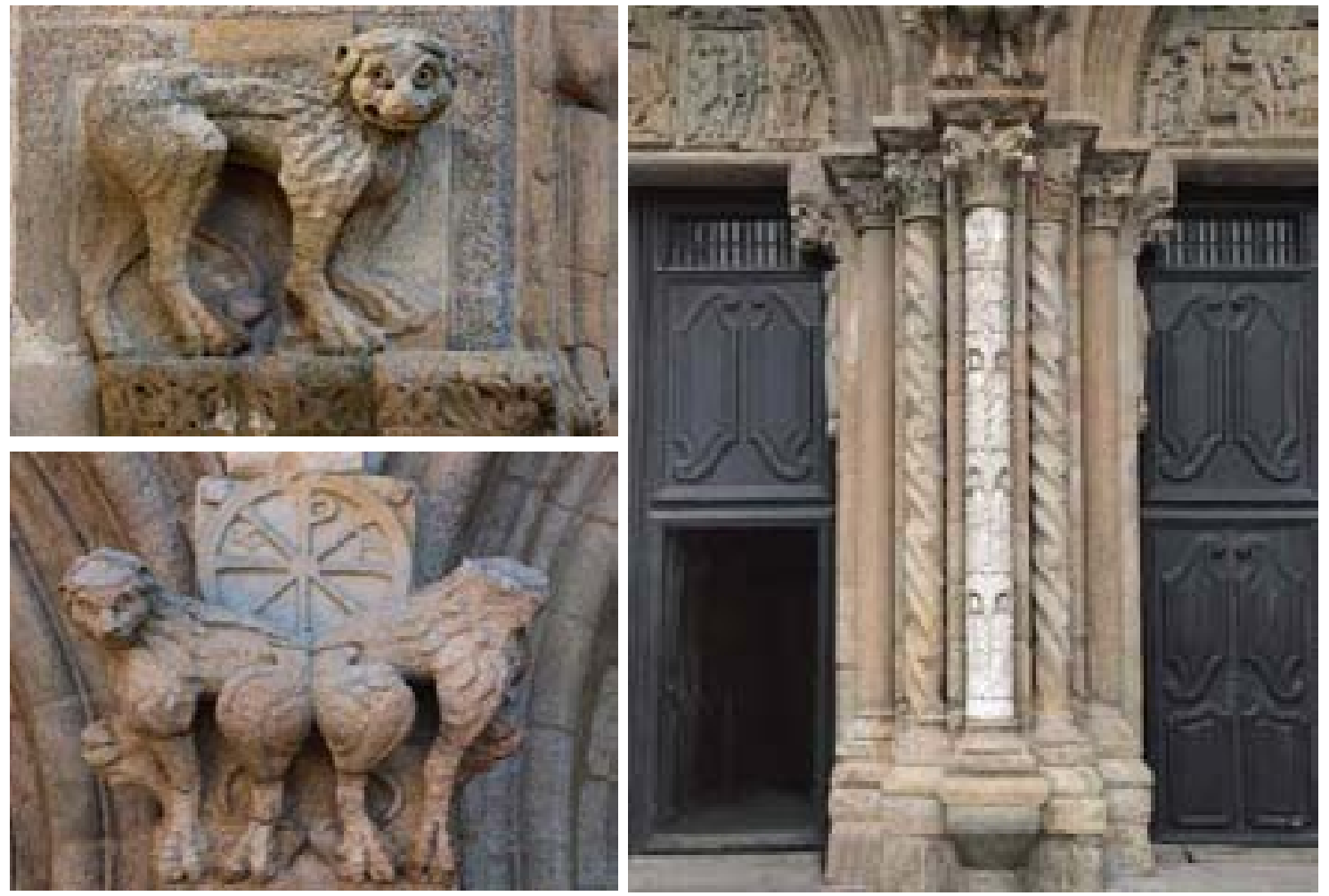

Figura 25. Leones y columnas de Platerías.

Y no se ha de echar en olvido que junto a la escena de las tentaciones del Señor, está representada una mujer que sostiene en sus manos la cabeza putrefacta de su amante, arrancada por el propio marido, quien la obliga a besarla dos veces por día. iGrande y admirable castigo para contárselo a todos el de esta mujer adúltera! 


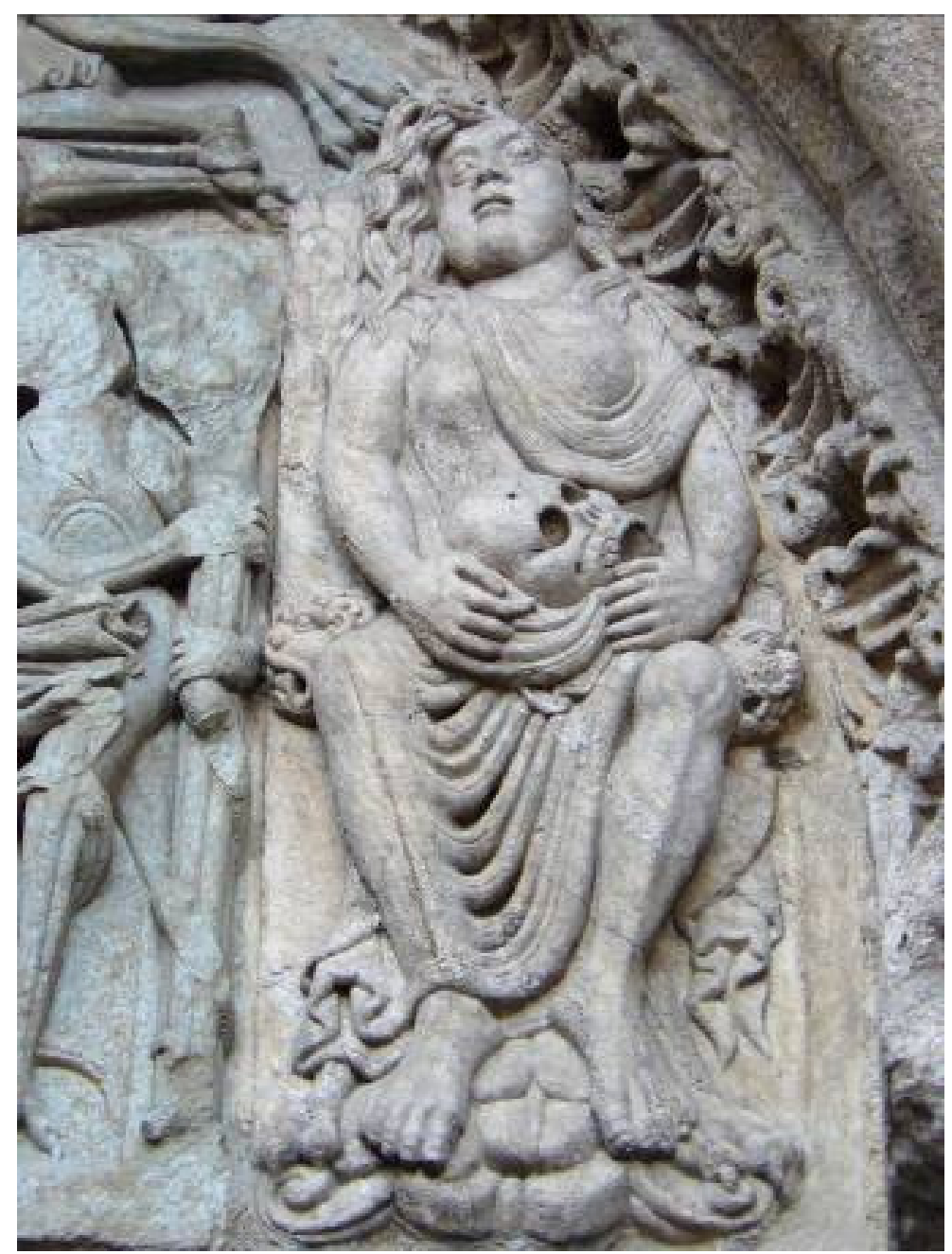

Figura 26. Mujer adúltera.

Los que creen que la interpretación de Picaud es la correcta, piensan que el mensaje moralizante queda formalmente claro: ella aparece desaliñada, desgreñada, con el pelo suelto, lo que en los convencionalismos de la época nos deja entrever su desorden moral (figura 26). Ahora bien, como observa justamente el profesor Muñoz Jiménez (2010: 77), la iconografía románica, "debida a la mente de los monjes más cultos, resulta muchas veces de cerrado simbolismo y difícil interpretación". Estamos ante una imagen sin letrero y hay interpretaciones para todos los gustos: alguno ve la representación de la belleza y juventud frondosa de la mujer que afronta la realidad de la muerte; belleza y juventud enfrentadas a decrepitud y muerte, que en una iglesia de peregrinación simbolizaría la brevedad de la vida, que vita est peregrinatio. Otros identifican a Eva, con alusión al Pecado Original. La lujuria, que también se sugiere, se suele representar como una mujer semidesnuda a la que distintos animales repugnantes muerden sus órganos genitales, como sucede en el Pórtico de la Gloria, en la fachada de Santa María la Real de 
Sangüesa, o en San Miguel de Estella, por citar ejemplos en el Camino. Sea lo que sea, es posible que se trate de una pieza recolocada tras los sucesos de 1117 . Pero continuemos con la descripción:

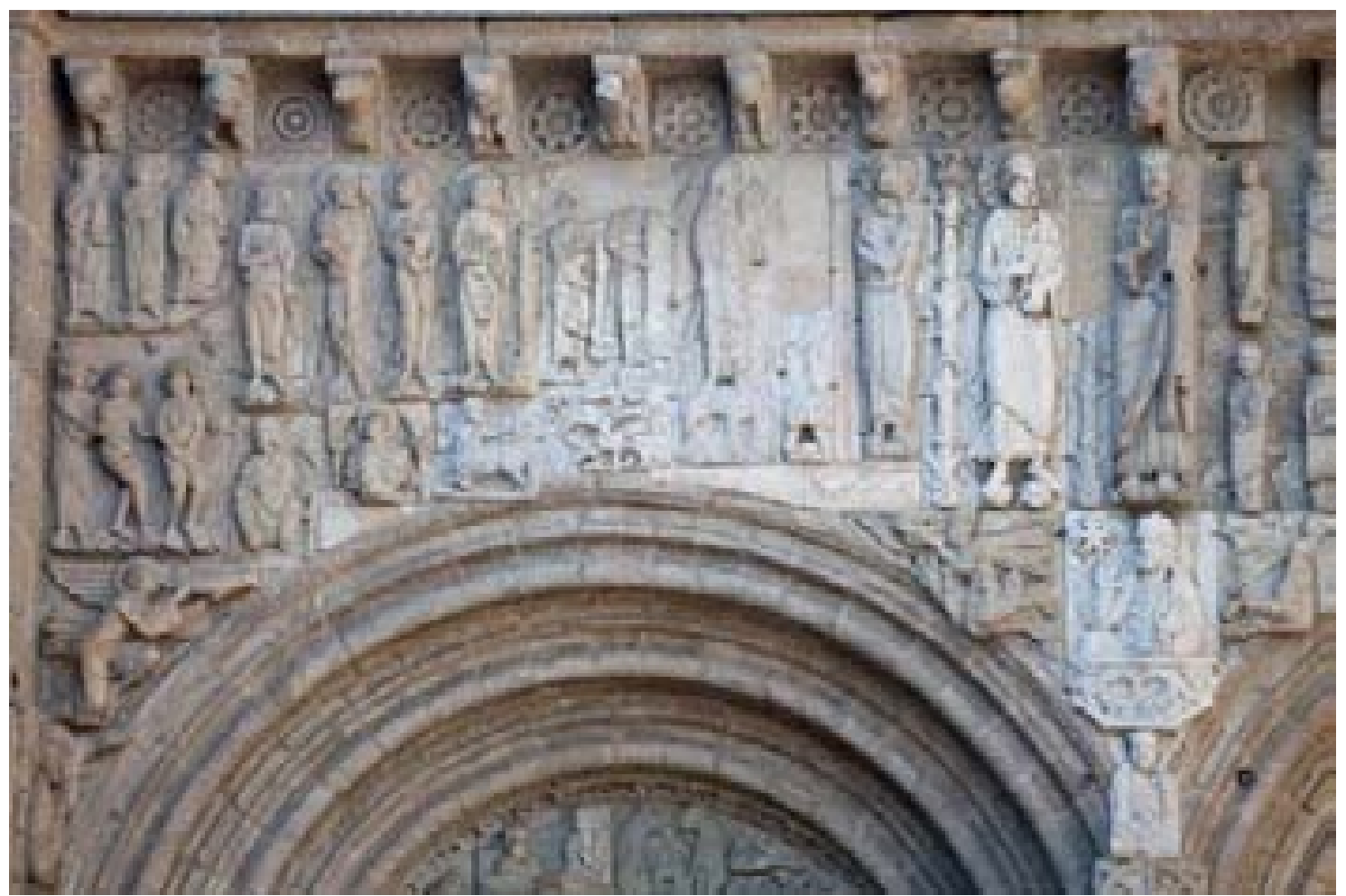

Figura 27. Friso superior de Platerías.

En la zona superior, sobre las cuatro puertas, hacia el triforio de la iglesia, resplandece con hermosura un llamativo conjunto de piezas de mármol blanco. Aparece, en efecto, allí el Señor en pie, San Pedro a su izquierda con las llaves en las manos, Santiago a la derecha entre dos cipreses, y junto a él, su hermano San Juan. A derecha e izquierda están los demás apóstoles [figura 27]. 


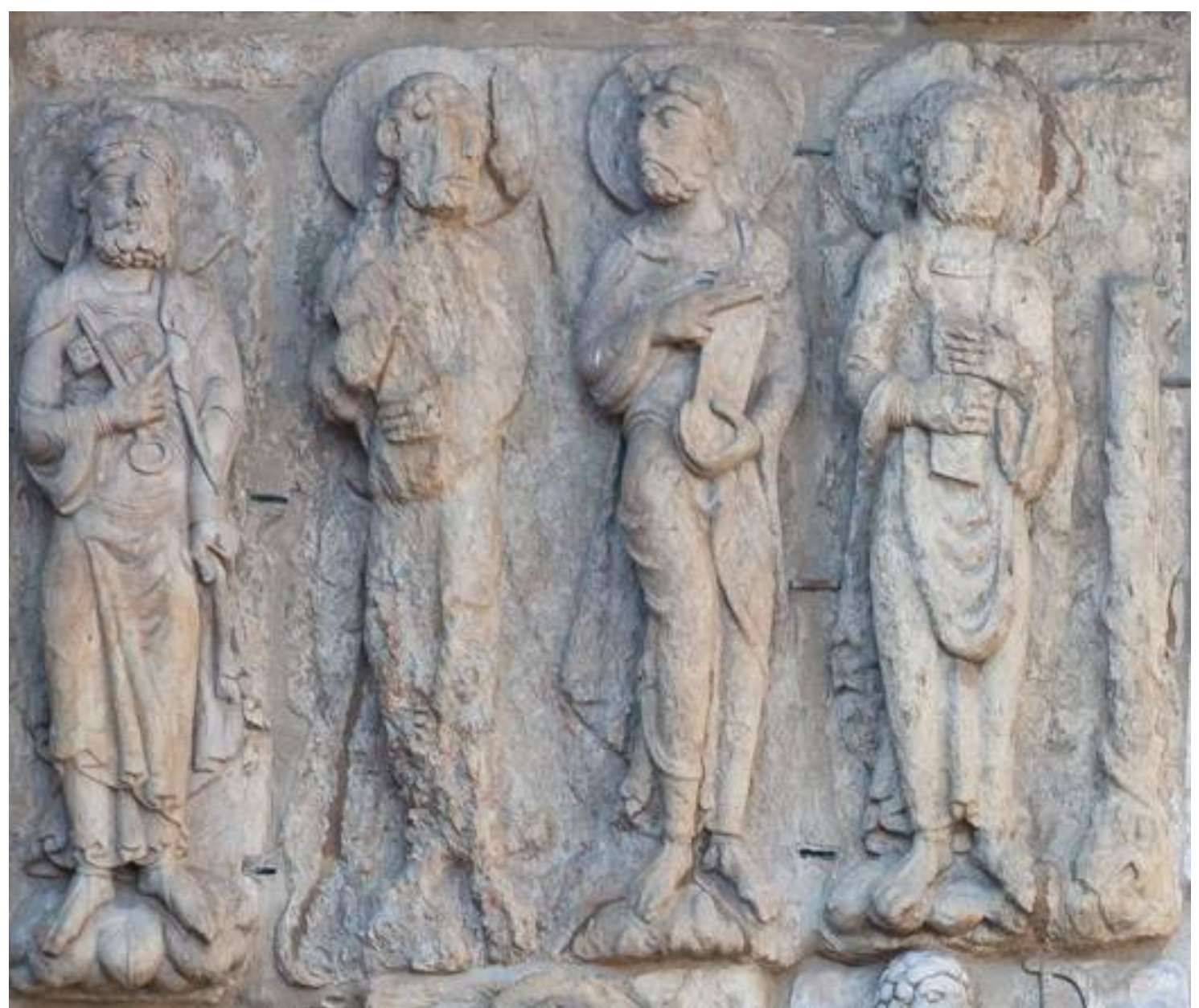

Figura 28. San Pedro y otros apóstoles.

Así pues, el muro, por arriba y por abajo, a derecha e izquierda, está bellamente labrado con flores, hombres, santos, bestias, aves, peces, y otros motivos que no podemos describir. Finalmente, sobre los ciborios, hay cuatro ángeles con sendas trompetas que anuncian el día del juicio.

Los ángeles con trompetas añaden una dimensión escatológica a los leones mencionados antes (figura 29). En Chartres la puerta meridional representa el Juicio Final. 


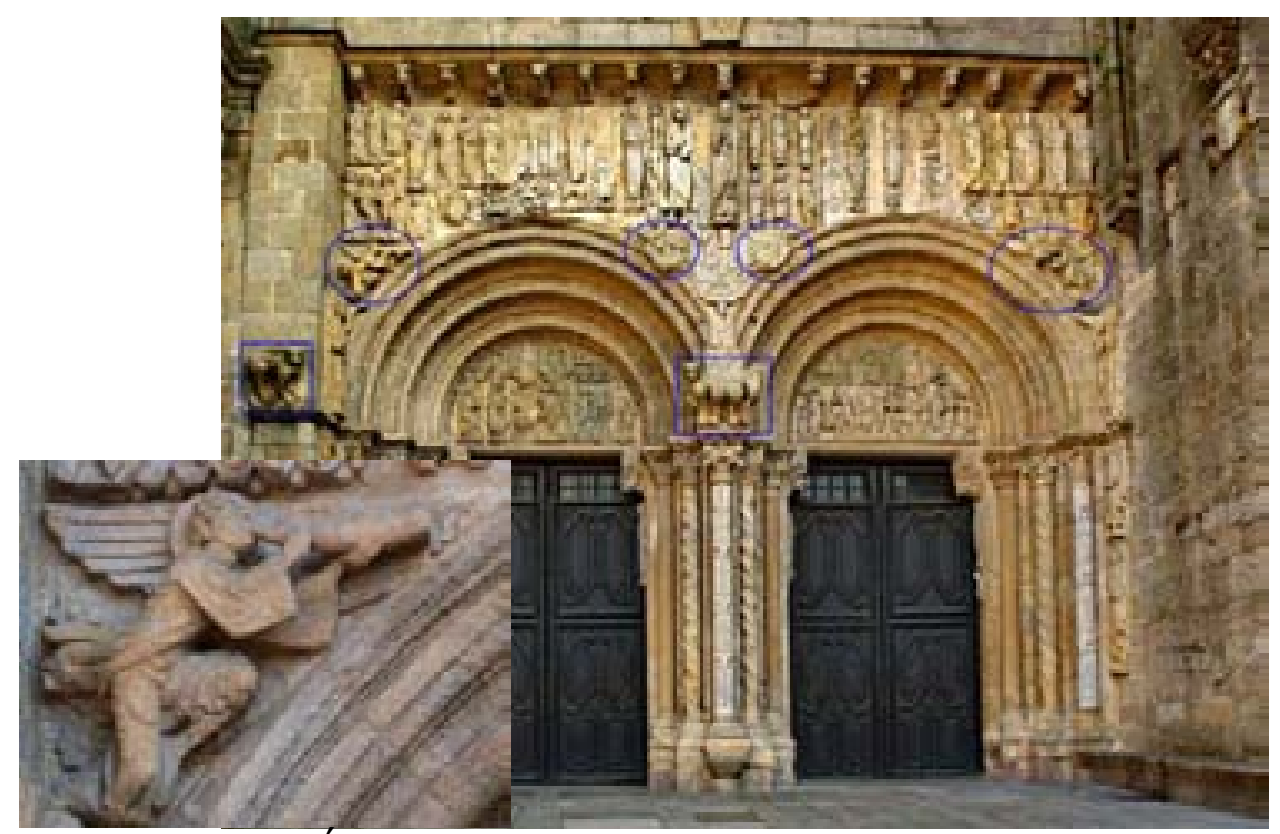

Figura 29. Ángeles con trompetas y leones en Platerías.

Esta segunda plaza pública que se abre delante de la portada Sur fue el escenario de numerosos juicios. En la documentación de la Edad Moderna dicho espacio se denomina "lugar sagrado" y, como tal, estaba cercado por unas cadenas de hierro y proporcionaba a cuantos se acogieran a él la inmunidad eclesiástica.

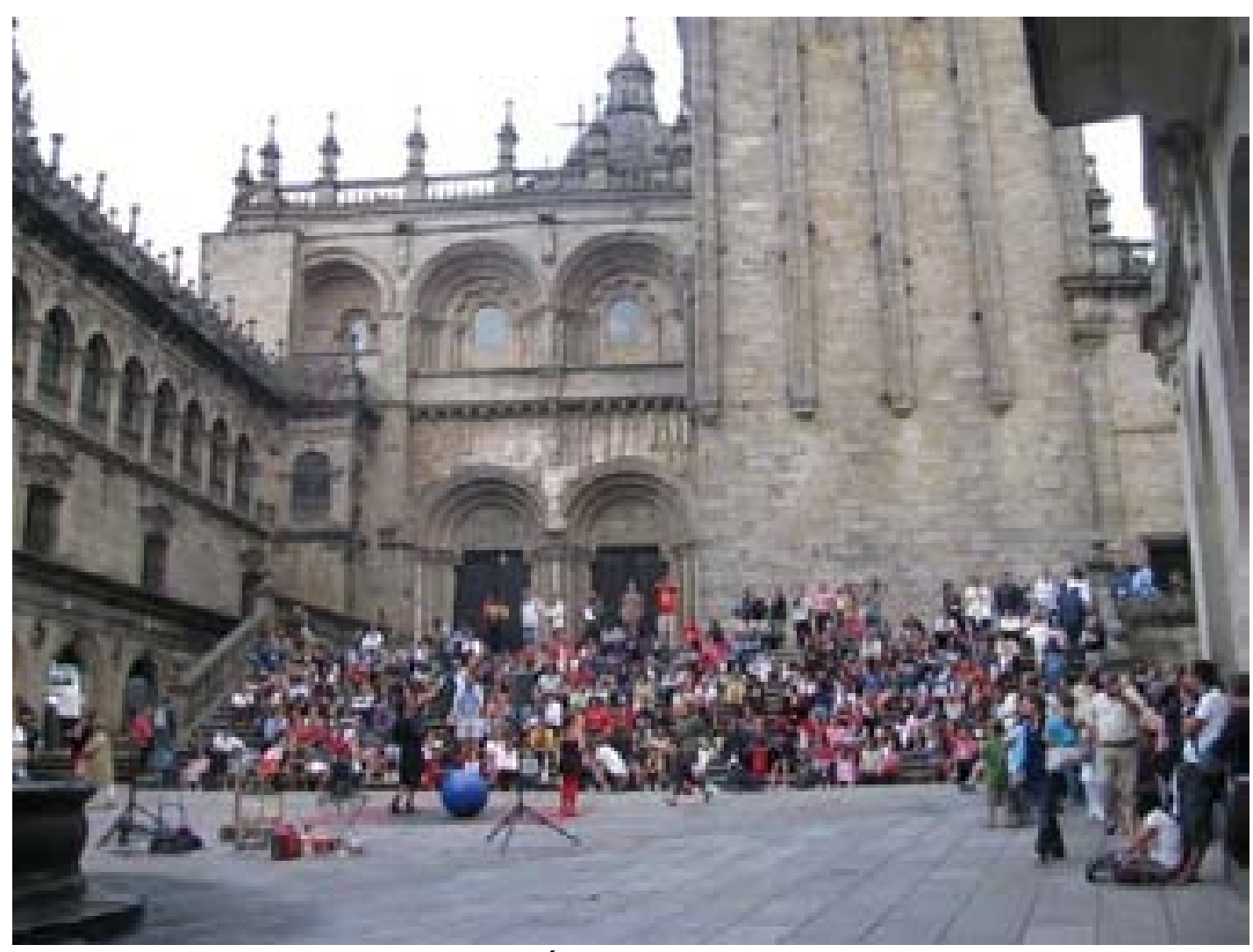

Figura 30. Un espectáculo donde antes hubo juicios. 
Quedaba, como es lógico, dentro del recinto de la primitiva muralla del locus sanctus apostólico elevada por el obispo Sisenando II. Según la Historia Compostelana (I, 96, 14), compuesta por orden de Gelmírez en 1139, "los viernes de cada semana, abiertas las puertas del palacio pontifical -Pontificali palatii januis referatis-, expónganse las querellas e injurias que hubiese, en presencia del pontífice, de los jueces y de los canónigos, y resuélvanse". Por eso en la revuelta compostelana de 1116-1117 los ciudadanos prendieron fuego a aquel escenario, expresión del poder feudal. ¿Tendría la fachada del palacio algún tipo de decoración escultórica en consonancia con la puerta meridional de la catedral?

\section{El pórtico Oeste}

Aquel "llamativo conjunto de piezas de mármol blanco" de la parte superior al que se refería Picaud, probablemente corresponde a algunas de las placas realizadas por el Maestro de la Transfiguración para una portada Oeste que, posiblemente, no llegó a montarse nunca. Picaud la describe así:

La puerta occidental, con sus dos entradas, supera a las demás en belleza, proporciones y ejecución. Es más grande y más hermosa que las demás y está más finamente ejecutada; desde fuera se accede por numerosos peldaños y está decorada con columnas de mármol de diversos tipos, con distintas representaciones y de varios estilos: hombres, mujeres, animales, aves, santos, ángeles, flores y adornos de diversa índole. Son tantos los motivos que la decoran, que me es imposible describirlos. Sin embargo, señalemos, que en la parte de arriba está bellamente esculpida la transfiguración del Señor, tal cual sucedió en el monte Tabor. Aparece, en efecto, en ella el Señor envuelto en una blanca nube, con el rostro resplandeciente como el sol y la túnica refulgente como la nieve; el Padre le habla desde lo alto, mientras que Moisés y Elías, que se aparecieron al mismo tiempo, hablan con Él de la muerte que había de afrontar en Jerusalén. Allí aparecen también Santiago, Pedro y Juan, a quienes el Señor reveló su Transfiguración con preferencia a los demás. Otro apóstol sin identificar está detrás de Santiago. 


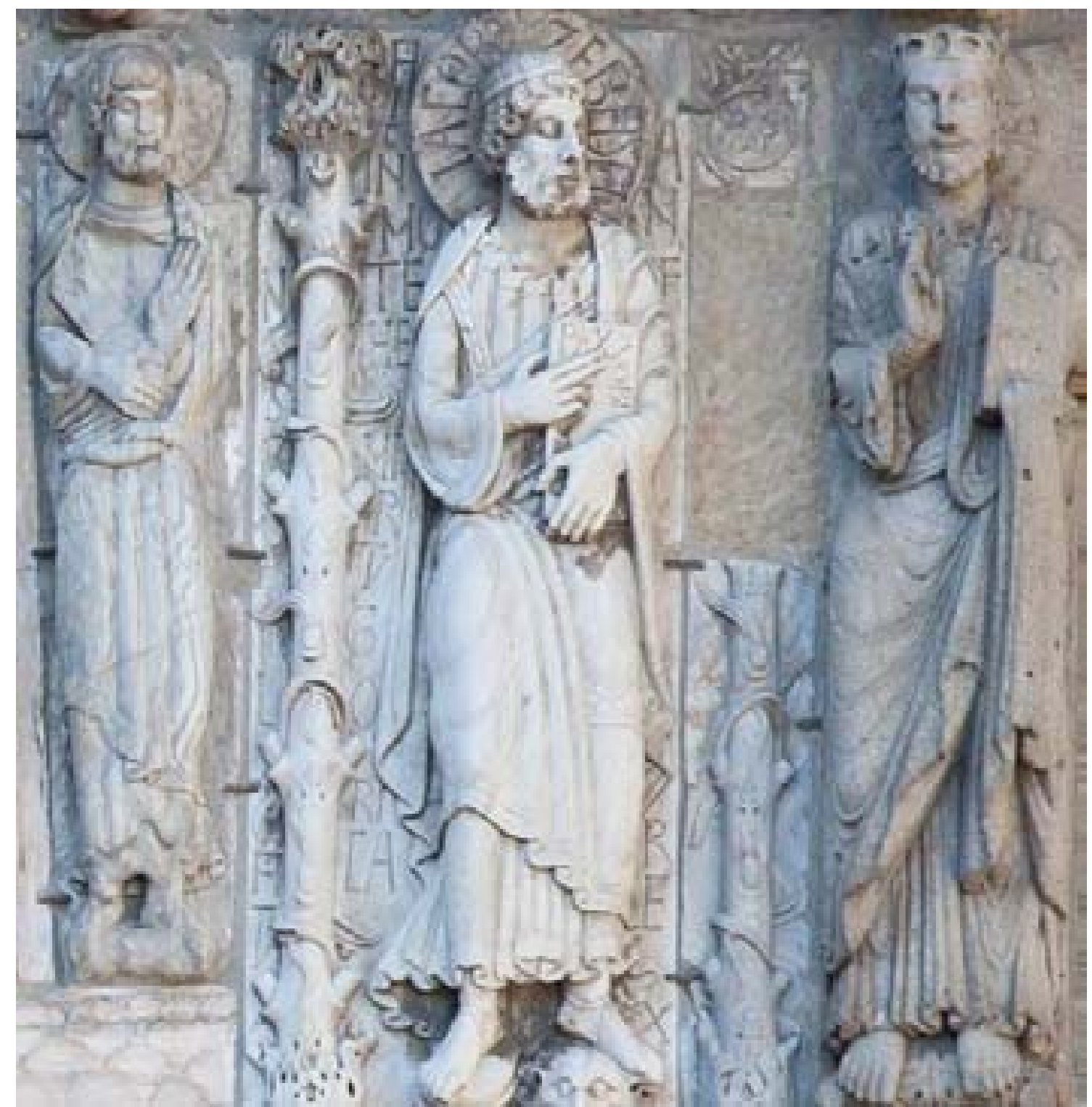

Figura 31. Apóstol, Santiago y el Salvador.

El la parte superior de Platerías (figura 22) encontramos la imagen de Santiago con la Inscripción "ANFUS REX" en el lado derecho (figura 31), seguramente recordando la coronación de Alfonso VII como rey de Galicia y León en 1111 . En su nimbo se lee "IACOBVS CEBEDEI"; en el lateral izquierdo: "HIC IN MONTE IHESV MIRATUR GLORIFICATV", y sobre la tablilla o libro que porta: "PAX BOVIS". A su derecha hay un San Andrés de la misma procedencia. Podemos ver abajo, en el centro, a Abraham saliendo del sepulcro bajo el cual hay una imagen del demonio, vencido (figura 32). Las aves picoteándose las patas pueden representar el deseo de liberarse de las ataduras terrenas para volar, como hace Abraham al resurgir de la tierra. 

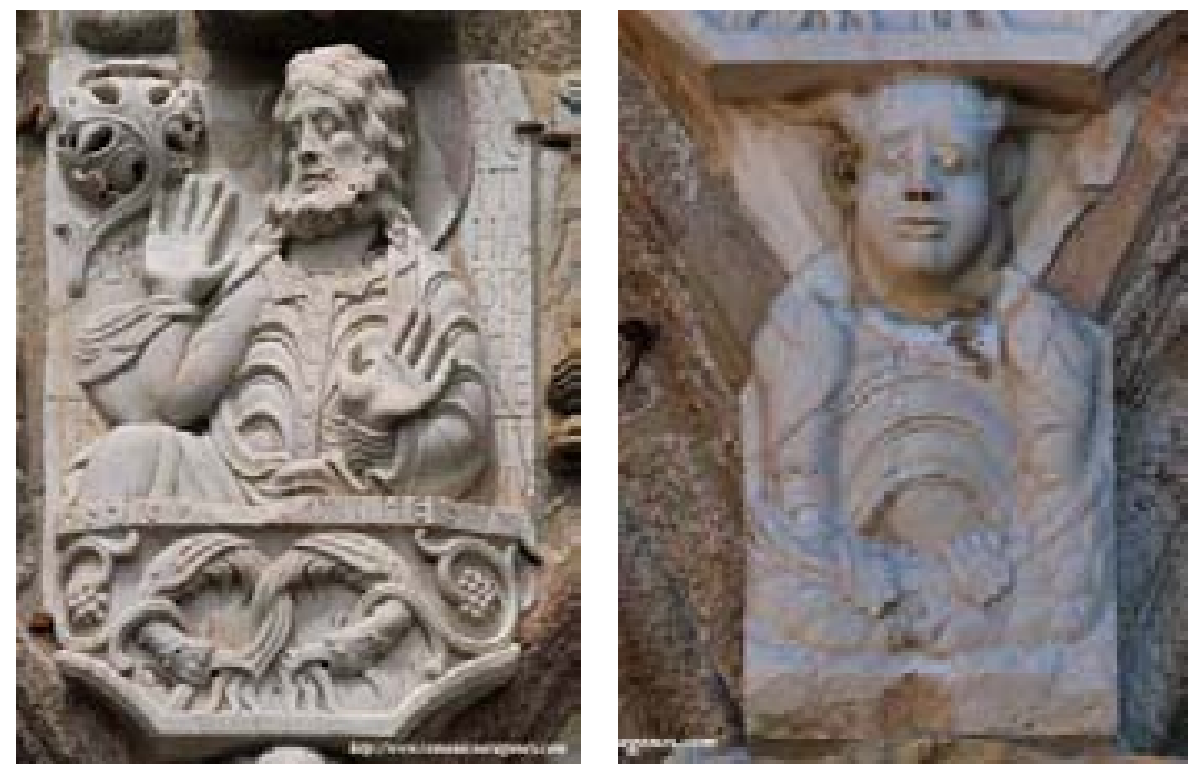

Figura 32. Abraham saliendo de su tumba y Demonio vencido.

Respecto a la actual puerta Oeste, el profesor Bango Torbiso (1998) señala que, con el brazo mayor de la catedral sin acabar de edificar, se presentó un serio problema estructural causado por la inclinación del terreno desde la cabecera hacia los pies del templo que hizo temer por su ruina. De modo que la tarea asignada al borgoñón maestro Mateo en 1168 sería la de detener la ruina del templo. Lo hizo erigiendo un espectacular contrafuerte a poniente, consistente en cripta, pórtico y torres que, junto a los últimos tramos de la nave, anclaron los pies del templo y detuvieron el empuje de la obra hecha (figura 33).

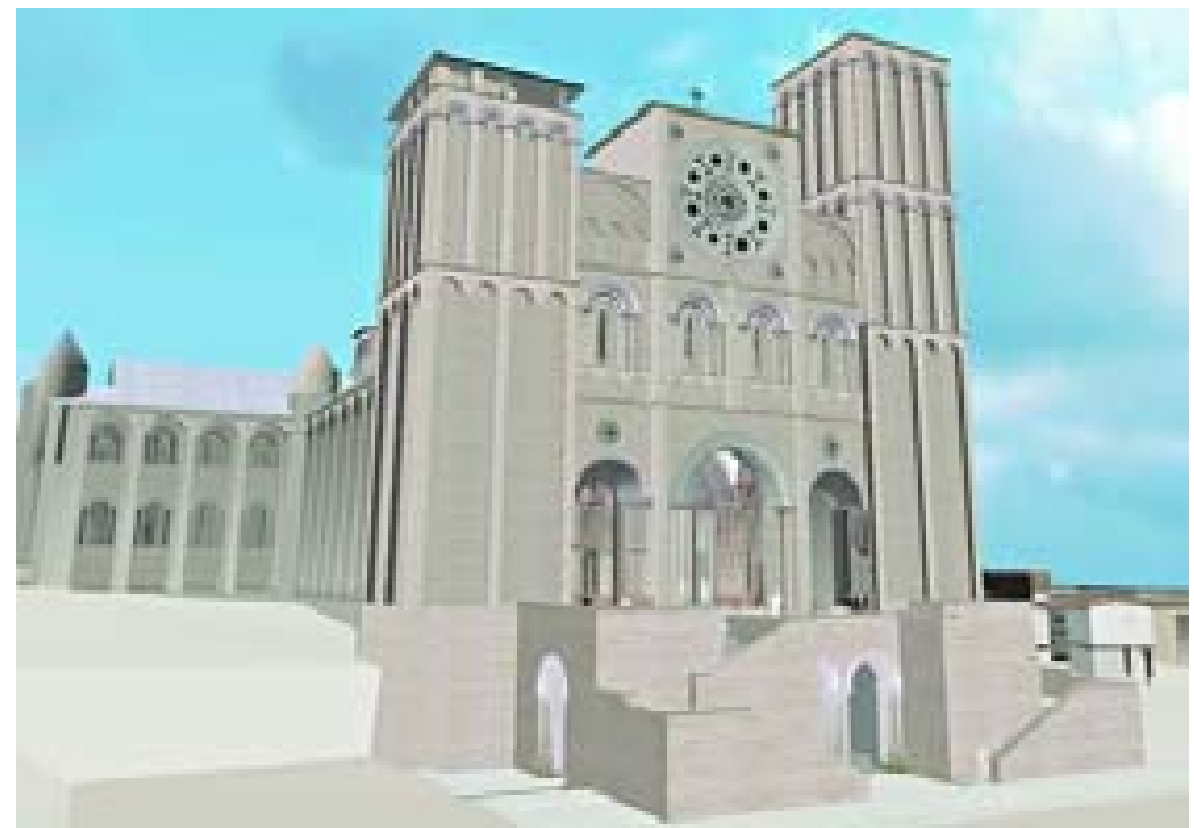

Figura 33. Cuerpo occidental del maestro Mateo. 
La portada Oeste actual es obra del mismo Maestro Mateo (cuya presencia se documenta en Galicia entre 1168 y 1217 ) y se adosó a los pies de la catedral en el último tercio del siglo XII (su terminación aparece fechada en 1188), posteriormente al viaje de Aymeric Picaud. La decoración de esta fachada parece representar la Jerusalén celeste (Martín González 1974: 441). El pórtico despliega un programa escultórico muy extenso, que envuelve al espectador una vez que accede al nártex. Su belleza obliga a perdonar la dispersión de las tallas preparadas para el primitivo pórtico occidental.

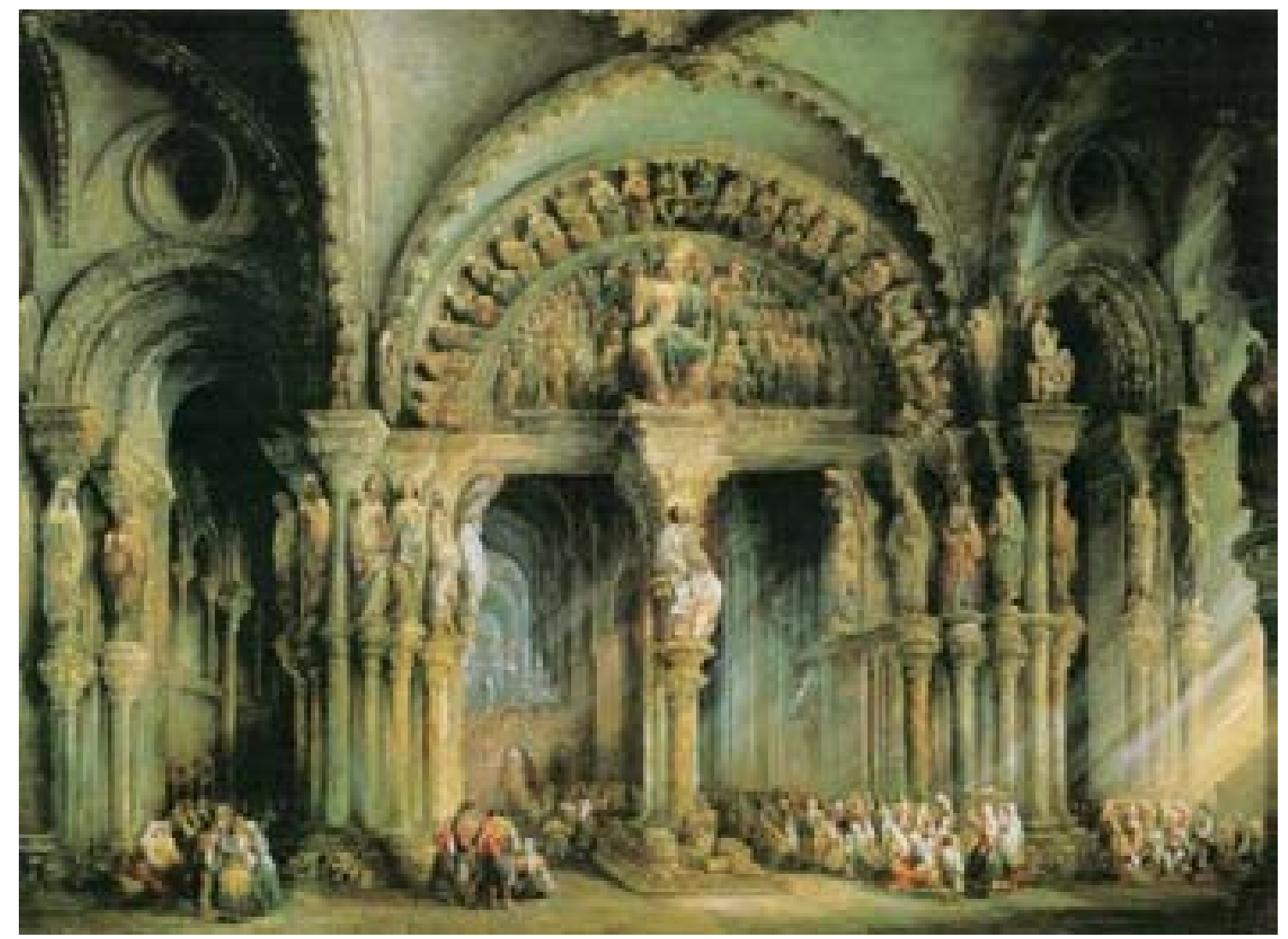

Figura 34. El Pórtico de la Gloria en un cuadro romántico de Pérez Villaamil, cuando todavía no había perdido la policromía de resultas de la obtención de un molde para el Victoria \& Albert Museum. La pintura otorga a las esculturas tanta vida y realidad como a los fieles, y la Jerusalén Celestial se hace presente: "Y vi la Ciudad Santa, la nueva Jerusalén, que bajaba del Cielo, de junto a Dios, engalanada como una novia ataviada para su esposo" (Ap 21:2). 
Correspondiendo a esta fachada se diseñó, ya en el Renacimiento, una tercera plaza de grandes dimensiones, la del Obradoiro. La escalinata manierista que salva el desnivel, nuevas torres y galerías, el claustro, otras portadas, la espectacular fachada barroca de Casas Novoa, fueron envolviendo la catedral, al tiempo que ésta se proyectaba en un urbanismo de tipo sacro que iba dando forma a la ciudad, con su red de calles porticadas, sus plazas, escalinatas, iglesias, fachadas espectaculares, perspectivas, etc.

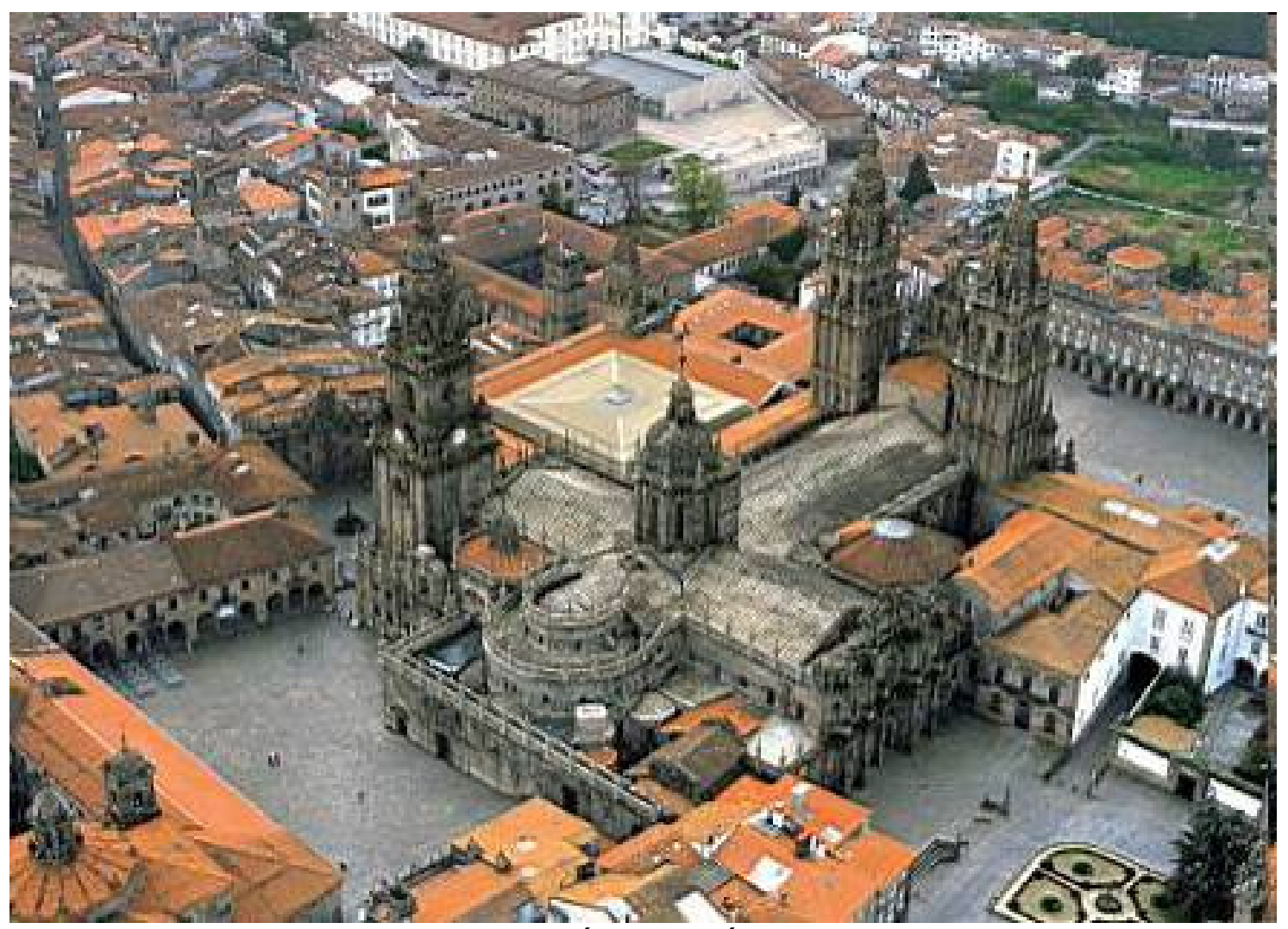

Figura 35. Vista aérea del área catedralicia. 


\section{Bibliografía}

ANÓNIMO (1994): Historia Compostelana. Edición de Emma Falque Rey. Madrid: Akal.

BANGO TORBISO, Isidro (1998): El Camino de Santiago. Madrid: EspasaCalpe.

BRAVO LOZANO, Millán (1989): Guía del peregrino medieval ("Codex Calixtinus"). Sahagún: Centro de Estudios Camino Santiago.

GARCÍA DE CORTÁZAR, José Ángel (1994): "El hombre medieval como homo viator: peregrinos y viajeros", en $V$ Semana de Estudios Medievales, Nájera, 1993. Nájera: Instituto de Estudios Riojanos.

GARCÍA TURZA, Javier (2000): "Lo imaginativo y lo real en la figura de Santiago", en El Camino de Santiago y la Sociedad Medieval, pp. 1529. Logroño: IER.

LECLERCQ, Henri (1927): "Jacques le Majeur", en Dictionnaire d'Archéologie Chrétienne et de Liturgie, VII, 2, pp. 2.089-2.109. Paris: Letouzey et Ané.

MANEL, T. (s.f.): "San Anselmo de Canterbury. Vida y teología", en San Anselmo. Roma: Pontificio Ateneo San Anselmo. En: http://www.santanselmo.org/doc pdf/seminario/epist oraz pdf/15\% 20Manel\%20Teol\%200r.pdf [Consulta: marzo de 2011].

MARTÍN GONZÁLEZ, J. J. (1974): Historia del arte. Madrid: Gredos.

MARTÍNEZ SOPENA, P. (1991): "Sobre los cultos del Camino de Santiago en los reinos de Castilla y León. Génesis y evolución", en Actas de la XVIII Semana de Estudios Medievales, pp. 157-172. Estella: Gobierno de Navarra.

MUÑOZ JIMÉNEZ, José Miguel (2010): Arquitectura, urbanismo y paisaje en los santuarios españoles. Madrid: Gea Patrimonio.

SÁNCHEZ ALBORNOZ, Claudio (1977): España, un enigma histórico. Barcelona: Edhasa.

VV AA (1992): Obra completa de Gonzalo de Berceo. Madrid: Espasa-Calpe. VV AA (1998): Huellas Jacobeas. Salamanca: Xunta de Galicia.

WADE LABARGE, Margaret (1992): Viajeros medievales. Los ricos y los insatisfechos. Madrid: Nerea.

YZQUIERDO, Ramón (2010): Santiago de Compostela en la Edad Media. Madrid: Edilupa. 